\title{
Understanding South Africa's Economic Puzzles
}

\author{
Dani Rodrik
}

CID Working Paper No. 130

August 2006

(C) Copyright 2006 Dani Rodrik and the President and Fellows of Harvard College

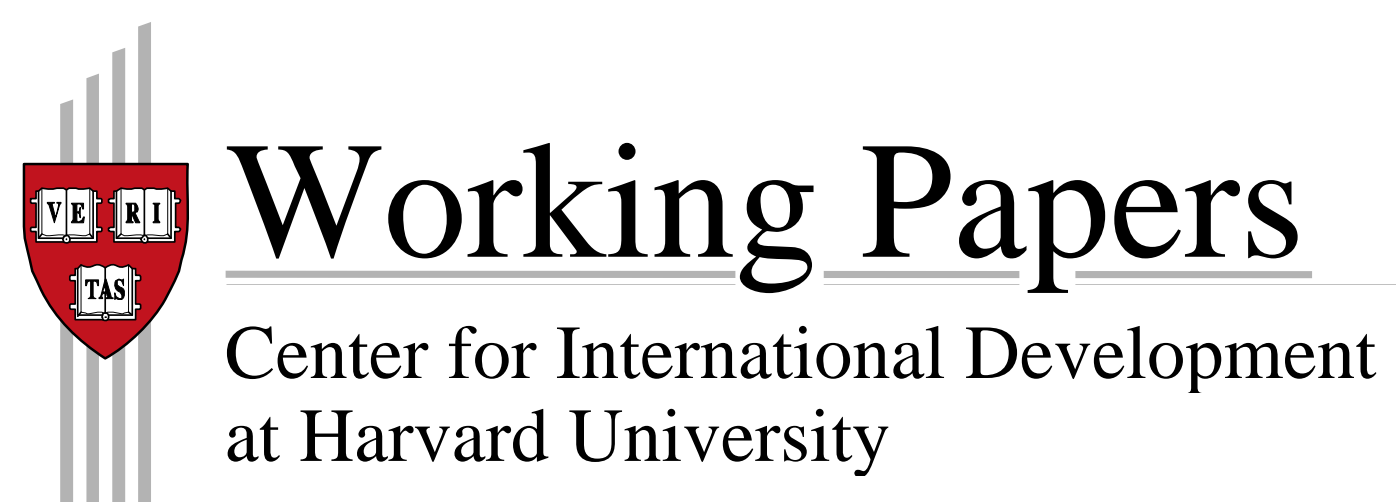




\title{
Understanding South Africa’s Economic Puzzles
}

\author{
Dani Rodrik
}

DRAFT, August 2006

\begin{abstract}
South Africa has undergone a remarkable transformation since its democratic transition in 1994, but economic growth and employment generation have been disappointing. Most worryingly, unemployment is currently among the highest in the world. While the proximate cause of high unemployment is that prevailing wages levels are too high, the deeper cause lies elsewhere, and is intimately connected to the inability of the South African to generate much growth momentum in the past decade. High unemployment and low growth are both ultimately the result of the shrinkage of the nonmineral tradable sector since the early 1990s. The weakness in particular of exportoriented manufacturing has deprived South Africa from growth opportunities as well as from job creation at the relatively low end of the skill distribution. Econometric analysis identifies the decline in the relative profitability of manufacturing in the 1990s as the most important contributor to the lack of vitality in that sector.
\end{abstract}

Keywords: South Africa, unemployment, manufacturing

JEL Codes: O55, O10, O14

This paper is part of the South Africa Growth Initiative. The Center for International Development has convened an international panel of economists and international experts from Harvard University, the Massachusetts Institute of Technology, the University of Michigan, and other institutions to work with South African economists to study that country's constraints to and opportunities for accelerated growth. This project is an initiative of the National Treasury of the Republic of South Africa within the government's Accelerated and Shared Growth Initiative (ASGI-SA), which seeks to consolidate the gains of post-transition economic stability and accelerate growth in order to create employment and improve the livelihoods of all South Africans.

I have greatly benefited from the guidance and insights of Trevor Manuel, Alan Hirsch, Lesetja Kganyago, and Ismail Momoniat. I also thank Johannes Fedderke, Dave Kaplan, Ben Smit and members of the CID team for feedback on the ideas presented here. Oeindrila Dube and Robert Mitchell provided research assistance.

Comments: dani_rodrik@harvard.edu 


\section{UNDERSTANDING SOUTH AFRICA’s ECONOMIC PUZZLES}

Dani Rodrik

August 2006

\section{$\underline{\text { I. Introduction }}$}

The transformation that South Africa has undergone since its democratic transition in 1994 is nothing short of remarkable. Prior to 1994, the South African economy and polity were dominated by the white minority, and even though the Apartheid regime had begun to unravel in the 1980s, the majority blacks remained deprived of basic political and economic freedoms. Given the depth of the racial and income divides that prevailed, it would not have been unreasonable to predict a cycle of redistribution and macroeconomic populism following democratization that would wreak havoc with the economy and turn the country into a sham democracy.

Instead, the democratically elected governments led by the African National Congress (ANC) have managed to create a stable, peaceful, and racially balanced political regime with an exemplary record of civil liberties and political freedoms. Economic policy has been conducted in an equally exemplary manner, with South Africa turning itself into one of the emerging markets with the lowest risk spreads. While South Africa has instituted some innovative (and expensive) social transfer programs to address long-standing disparities, it has done so in the context of cautious fiscal and monetary policies which have kept inflation and public debt at low levels. There were no nationalizations or large-scale asset redistributions. Moreover, the economy was opened to international trade and capital flows. ${ }^{1}$

If the world were fair, political restraint and economic rectitude of this magnitude would have produced a booming South African economy operating at or near full employment.

\footnotetext{
${ }^{1}$ See Hirsch (2005) for an excellent account by an insider. Other perspectives on South African growth performance include Fedderke (2002), Hartzenberg and Stuart (2002), and du Plessis and Smit (2006).
} 
Unfortunately, it has not turned out that way. In the decade since 1994, per-capita GDP grew at an average rate of 1.2 percent per annum - a rate that is comparable to that of sub-Saharan Africa (1.1 percent) and Latin America ( 0.8 percent), and considerably below that of South Asia (3.7 percent) and East Asia (6.2 percent). As Figure 1 shows, South Africa's income level has yet to catch up with its peak level attained in 1980. And investment remains low at around 17 percent of GDP (although the bulk of the overall decline in the investment effort since 1970s is due to the reduction in public investment).

The most worrying aspect of this disappointing economic performance is unemployment. South Africa's unemployment rate today stands at 26 percent according to the narrower definition of who is unemployed, and at 40 percent if one includes discouraged workers (Banerjee et al., 2006). This is one of the highest rates of unemployment anywhere in the world (see Figure 2 for some international comparisons). Furthermore, unemployment appears to have increased particularly rapidly since the democratic transition (from a "low" of 13 percent in 1993). (The lack of labor force surveys makes it difficult to know what the comparable unemployment rates were in the 1980s.) As would be expected, unemployment is heavily concentrated among the young, unskilled, and the black population. This poor record on employment represents not only an economic tragedy, it poses a significant threat to the stability and eventual health of the South African democracy.

The proximate cause of high unemployment is that prevailing South African wages are too high compared to real wage levels that would clear labor markets at lower levels of unemployment. Trade unions and wage bargaining play an important role in wage determination in South Africa. The trade union confederation COSATU (Congress of South African Trade Unions) is a partner in the governing coalition dominated by the ANC. A cursory comparison of 
wages across countries would show that South African wages (in the formal sector) are quite high by the standards of countries at similar income levels. On the other hand, real wages have not risen much (if at all) since the transition to democracy (Leibbrandt et al. 2005), and to the extent that unions have prevailed, it seems to have been mostly to prevent the real wages of their members from falling (Banerjee et al. 2006). The evidence I will show later in the paper suggests that wage-push has not been a significant factor in determining patterns of structural change in the South African economy during the 1990s.

The deeper cause of South African unemployment lies elsewhere, and it is intimately connected to the inability of the South African to generate much growth momentum in the past decade. High unemployment and low growth are both ultimately the result of the shrinkage of the non-mineral tradable sector since the early 1990s. The weakness in particular of exportoriented manufacturing has deprived South Africa from growth opportunities that other countries have been able to avail themselves of. The point is perhaps best made by comparing South Africa to a high-growth economy such as Malaysia, a country with which South Africa shared many common features in the 1980s. As I will show in the next section, the main difference between these two countries is that Malaysia was able to pull an increasing share of its workforce into manufacturing — the sector with the highest labor productivity in the economy—while in South Africa manufacturing lost ground to the tertiary sector.

The reason that this pattern of structural change is also a key driver of unemployment is that in South Africa non-mineral tradables (including manufacturing) are intensive in low skilled labor compared to services. The relative shrinkage of manufacturing (along with economy-wide skill upgrading) has entailed a collapse in demand for relatively unskilled workers. This need not have turned into a growing unemployment problem among the unskilled if one or both of two 
things could have happened. First, a large enough decline in real wages at the low end of the skill distribution could have compensated for the inward shift of the labor demand schedule. But this was an unrealistic option in view of the social expectations and political realities created by the democratic transition. Second, the growing mass of job seekers could have been absorbed into the informal sector (where wages and work conditions are considerably more flexible). This second mechanism is how developing countries elsewhere have coped with similar labor market problems. But while informal employment has grown rapidly in South Africa, its level remains quite low by the standards of developing countries (see Table 2 below). This is no doubt one of the legacies of the Apartheid regime - which made it first illegal and then difficult for blacks to move to larger urban areas unless they already had a certified job. In the absence of sufficient real wage adjustment and informal sector growth, the decline in the demand for low skilled workers has resulted in high unemployment. ${ }^{2}$

A key implication follows from this diagnosis: expansion of non-mineral tradablesmanufacturing in particular — will be good both for growth and employment. An export oriented strategy that increases the relative profitability of producing tradables for world markets will generate economic growth by pulling labor into productive activities where their marginal product is much higher. And since tradables are relatively low-skill intensive in South Africa compared to service activities that have been the major beneficiary of recent patterns of structural change, such a strategy will entail shared growth rather than trickle-down growth. The cures for low growth and high unemployment are largely one and the same.

The plan of this paper is as follows. In section II, I provide a brief comparison with Malaysia to underscore the central role played by export-oriented manufacturing in Malaysia's

\footnotetext{
${ }^{2}$ One needs to add the impact of rising female labor participation in the 1990s as well (Leibbrandt et al. 2005). Overall labor force participation still seems low in South Africa, however, by international benchmarks.
} 
growth performance. In section III, I turn to employment and examine the patterns of structural change that account for the decline in the demand for labor (especially low skill labor). In section IV, I provide an econometric analysis of the patterns of structural change to better pinpoint their sources. The econometrics identifies the decline in the relative profitability of manufacturing in the 1990s as the most important contributor to the lack of vitality in that sector. Section V concludes.

\section{Why is South Africa not Malaysia?}

The title of this section is not as crazy as it may sound at first. South Africa and Malaysia are both medium-sized economies with deep racial cleavages, in which an ethnic majority controls the polity but economic power lies with an ethnic minority. Table 1 shows some comparisons using the Hall and Jones (1999) database for 1988. As the table reveals, the economic structures of the two economies were strikingly similar at that time. Output per head and TFP were virtually identical — roughly at a quarter and a half of the U.S. level, respectively. Human capital levels were also quite close. And both economies had a similar dependence on mining.

But this snapshot hides important differences in the evolution of the structure of the two economies. Most importantly, Malaysia was undergoing a process of industrialization, while South Africa had begun to de-industrialize. Figure 3, which shows the trends in the share of the labor force employed in manufacturing in the two economies, tells a striking story. As of the mid-1980s, South Africa still had a larger manufacturing base: Roughly 12 percent of its total labor force was employed in manufacturing, compared to less than 8 percent in Malaysia. But since then, Malaysia has industrialized by leaps and bounds, with this number reaching 16 
percent a decade later. In South Africa, by contrast, the proportion of the workforce employed in manufacturing has come steadily down, to below 7 percent by 2000 . What is also remarkable in Malaysia's experience is that this pick-up in industrialization came after a period of what looked like a continuous decline in manufacturing in the early 1980s. The latter suggests that it is possible to reverse a trend deterioration in manufacturing performance, provided the policy framework is adequate (on which more later).

The expansion of manufacturing in Malaysia has been both growth and equity promoting. It has been good for growth, because as Figure 4 shows, manufacturing is the sector where labor is the most productive by far. Even if the productivity differences are smaller at the margin than on average, there are still large unexploited gains from moving labor into manufacturing from other activities. And it was equity promoting because much of the gains from this process of structural change accrued to the workers themselves.

If the South African economic structure moved in the opposite direction, it is not because manufacturing did not enjoy similar advantages in South Africa. While South African manufacturing appears not as productive as that of Malaysia, it still remains more productive than South African services (Figure 4). Why South Africa de-industrialized prematurely is therefore an important question, and one that I will analyze econometrically in section IV.

Manufactures are the quintessential tradables, and the different roads traveled by the two economies are perhaps most evident in their trade performance. Once again, the two economies started out in roughly similar positions. Around the mid-1970s, the share of manufactured exports in GDP stood at around 6-7 percent in both countries. By 2004, this figure had in creased to more than 80 percent in Malaysia, but only to 12 percent in South Africa. And as 
Malaysia developed its manufacturing base, it caught up with and surpassed South Africa in terms of the "sophistication" of its export basket (Figure 5).

There are of course a multitude of reasons that account for the different paths taken by the two economies. Malaysia was in a different neighborhood, one that was considerably friendlier to an export-oriented strategy. South Africa had to contend with the debilitating effects of the trade embargo it faced in world markets in the 1980s and its heavy spending on defense industries for the purpose of propping up the Apartheid regime. But one should not minimize the active role played by government to promote manufacturing (and manufactured exports) in Malaysia. Even though industrial policies went through various phases (for a summary, see Box 1), expanding and diversifying the industrial base of the economy remained an unwavering goal. Policies employed a mix of market signals and direct incentives through tax, trade, and labormarket interventions. Some of the industries spawned by these interventions have been failures (such as the national auto manufacturer, Proton, launched in the early to mid-1980s), but the successes (in electronics, for example) have been more than adequate to pay for these failures. Malaysia's experience is in line with other successful industrializers'. The productive diversification that economic growth requires is not an automatic process that well-functioning markets generate on their own; it requires an experimental, nurturing approach by the government in strategic collaboration with the private sector (Hausmann and Rodrik 2003, Rodrik 2004).

\section{Patterns of employment and structural change in South Africa}

Formal employment in South Africa has stagnated during the 1990s, despite the pick-up in economic growth since 1994 and the increase in labor force participation associated with 
democratization and the end of the Apartheid era (Figure 6). Semi- and low-skilled workers still constitute around 42 percent of those employed in the formal sector. ${ }^{3}$

The constancy of overall employment masks a tremendous structural change that has taken place within the economy over the last two decades or so. This can be seen in Figure 7, where I show the shares in total employment of three different types of economic activities: tradable activities (mining, agriculture, and manufacturing); private non-tradable activities (financial services, construction, trade, retail, transport, and other services); and public nontradable activities (utilities and government services). The figure shows a dramatic increase in the employment share of private non-tradables at the expense of tradables. The latter have come down from more than 40 percent of employment in the late 1970s to around 30 percent currently. What this reflects is a decline in agricultural and mining employment which has not been compensated by an increase in manufacturing employment. Among expanding sectors, financial intermediation, insurance, real estate and business services (F.I.R.E., SIC 8) have been particularly notable. That sector now employs as many workers as all of manufacturing taken together (around 15 percent of total formal employment).

This pattern of structural change implies a significant decline in the relative demand for low skill labor because the declining sectors constitute the least skill intensive parts of the South African economy. The skill intensity of the three sectors is shown in Figure 8, which displays the shares of low and skilled workers in sectoral employment. First, what is evident in the graph is that there has been across-the board skill upgrading in the economy, with the low-skilled share falling in all three sectors. Second, and more importantly, tradable sectors remain the most lowskill intensive part of the economy by far. As late as 2004, more than 70 percent of workers

\footnotetext{
${ }^{3}$ All data in this section, including the classification of workers by skill category come from the Quantec database, accessed through the TIPS (Trade and Industrial Policy Secretariat) website.
} 
employed in tradable industries were classified as "low and unskilled" workers. The corresponding figure in private non-tradables was only 25 percent. Even if we exclude mining and agriculture from tradables and focus on manufactures, there remains a big gap: slightly less than 60 percent of workers employed in manufacturing in 2004 were classified as low and unskilled.

The negative relationship between low-skill intensity and employment growth shows up also at finer levels of disaggregation. Figure 9 shows the pattern of structural change within manufacturing. The simple correlation between the initial share of semi- and unskilled workers and the subsequent increase in employment for the 28 subsectors within manufacturing is -0.41 .

This pattern of structural change helps explain the persistent concern in South African business and policy circles with a "skills shortage." The view that skills acts as a significant constraint on economic growth is widely held, and is reflected in the government's official policy document on the Accelerated and Shared Growth Initiative for South Africa (ASGI-SA). It is natural that a pattern of growth that has (thus far) emphasized the expansion of skillintensive tertiary sectors at the expense of low-skill intensive tradable sectors puts a premium on skills and human capital. On the other hand, if it is true, as I have argued, that higher levels of growth and employment creation require a different pattern of structural change—an expansion of low-skill intensive manufactures at the expense of skill-intensive non-tradables-skills can no longer be viewed as a serious constraint on future growth. In view of the patterns of skill intensity discussed earlier, manufactures-led growth would on balance reduce the relative demand for skilled workers.

A final trend worth emphasizing is capital deepening. The process of substituting capital for labor has been particularly marked in tradable activities (including manufacturing). 
Interestingly, this trend is confined to tradables: capital-labor ratios have remained more or less constant within the (private) non-tradable sector (Figure 10). The result is that tradable activities now employ considerably higher capital per worker than non-tradable activities.

To sum up, we have identified three important trends in the economy which together have put a significant damper on the demand for low skilled workers in South Africa. First, there has been substitution towards skilled workers within each economic activity. Second, there has been significant structural change away from the most low-skill intensive parts of the economy, namely tradables. Third, within tradables, production techniques have become progressively more capital-intensive. The first and third of these trends probably have a lot to do with ongoing patterns of technological change. Skill-biased technological change, in particular, has been a common feature of all open economies during the last two decades or so. But the reasons for the second trend are unclear, and since the structural shift against tradables relates closely to determinants of growth in South Africa, these reasons will be analyzed in the next section of the paper.

These shifts in the demand for labor (particularly low-skill labor) make it easier to understand why unemployment has trended up and is so high in South Africa. Of course, a rising unemployment could perhaps have been avoided by a commensurate decline in real wages for low-skilled workers. But this would have been a political impossibility in view of the democratic transformation in South Africa and the role played by unions in the anti-Apartheid struggle and the new democratic government. That is not to say that unemployment is itself without political cost. But the relatively generous social grants put in place by the democratic government has apparently taken the edge off what would have otherwise been a very serious social problem. There is some evidence that households view paid employment and social grants 
as substitutes at the margin. For example, households that lose a pension-eligible member subsequently report increased labor force participation (Rancchod 2006, as reported in Banerjee et al. 2006; see also Bertrand et al. 2003).

As discussed in the introduction, unemployment of the scale experienced by South Africa could also have been avoided if young, unskilled job seekers could be absorbed into the informal sector. The informal sector is the employer of last resort in most developing countries with institutionalized formal labor markets. But while informal employment has grown quite rapidly in South Africa, informality still does not present the large footprint one would have expected it to have. Informal employment (as a share of total non-agricultural employment) remains a fraction of what it is elsewhere in Africa, Latin America, and Asia (see Table 2).

The reasons why informality does not play a larger role in absorbing surplus labor remain unclear. One obvious candidate is the legacy of the Apartheid regime (and its pass laws in particular), which confined blacks who did not already have jobs to separate townships and prevented the unemployed from migrating into urban areas. Restrictive zoning and licensing regulations and periodic "slum clearance" efforts undermined fledgling informal activities. Even though the pass laws themselves were repealed in 1986 and democracy itself is more than a decade old, it is possible that this history delayed the creation of the social and other networks needed to maintain large-scale informality. Another possibility is the prevalence of high levels of crime, which acts as a particularly onerous tax on small-scale enterprises (Stone, forthcoming). Finally, the existing system of social grants presumably sets a higher reservation wage level in South Africa than in comparable countries, acting as a deterrent to lowproductivity informal activities (e.g. street peddling). 


\section{$\underline{\text { IV. Explaining patterns of structural change }}$}

In this section, I present an analysis of the determinants of recent patterns of structural change in South Africa, paying particular attention to the manufacturing sector. As explained earlier, the health of the manufacturing sector is vital to both growth and employment creation in South Africa. Understanding the lack of dynamism of this sector is therefore key to designing appropriate growth policies.

Formal employment in manufacturing has declined from 1.6 million in 1990 to 1.2 million in 2004. The fall in semi- and unskilled employment, from 1.0 million to 0.7 million, accounts for the bulk of this decline. What is the reason for this adverse trend? Figures 11, 12, 13 and 14 display some of the candidate explanations.

First, there has been an apparent fall in the relative price of the manufacturing sector. Figure 11 charts the relative price of manufacturing (value added price index of manufacturing divided by the GDP deflator) and shows that it tracks the behavior of manufacturing employment since the late 1970 s quite well. The decline in the relative price of manufacturing is of the order of 15 percent (if the GDP deflator is used as the denominator) and 50 percent (if the price of the

F.I.R.E. sector [SIC 8] is used as the denominator). When relative prices are adjusted by sectoral TFP growth (on the logic that a decline in output price can be offset by an increase in productivity), the relative profitability of manufacturing exhibits a decline of the order of 30 percent (Figure 12).

Second, the South African economy is now considerably more open to international trade and the manufacturing sector presumably faces much greater competitive discipline, regardless of whether firms are import-competing or export-oriented. Edwards and Lawrence (2006) report a drop in the import-weighted effective rate of protection from 35.6 percent in 1989 to 14 percent 
in 2000. As Figure 13 shows, import penetration levels have increased significantly within manufacturing, from an average of around 20 percent before 1990 to around 28 percent recently. Even though the work of Aghion, Braun, and Fedderke (2006) finds no evidence of decline in (average) markup ratios in South Africa, in view of the trade liberalization that has taken place to date it is difficult to believe that competitive pressure on manufacturing firms has not increased at the margin. I will provide some evidence below which suggests that this increase in import competition is one of the reasons behind the decline in manufacturing's relative price.

Third, we may consider the role played wage pressure. South African data do not break down wages by skill category, but average real remuneration in manufacturing shows a steep increase in the 1990s (Figure 14). Before we draw any conclusions from this, however, we need to bear in mind the trends in factor substitution that we discussed in the previous section: manufacturing has experienced both skill upgrading and capital deepening. The average worker is now more skilled and has greater productivity because s/he works with more capital. We have to explicitly control for this before we can ascribe employment decline to any element of wagepush.

Decomposing remuneration into skill-upgrading and wage-push components

We have data on total remuneration and skill composition of the workforce by sector. Therefore we can decompose changes in real sectoral remuneration into the following two components: (a) a part that is due to purely to changes in skill composition; and (b) a part that represents the skill-adjusted wage (the residual). I will call the first the "skill upgrading" component and the second the "wage push" component. Specifically, I first run the following regression: 


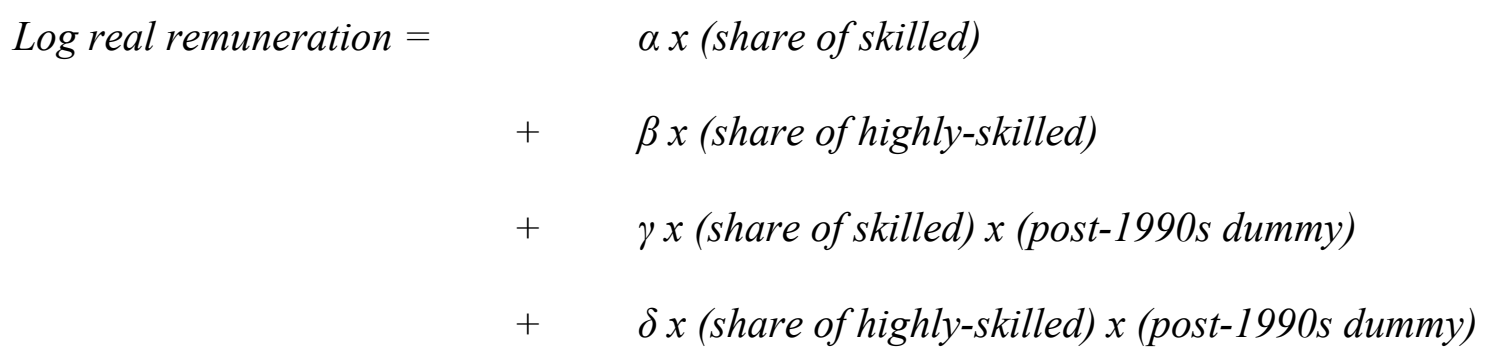

The regression is run across nine one-digit sectors over the 1980-2004 period with a full set of year and sector dummies. The results are shown in Table 3. The coefficients $\alpha$ and $\beta$ represents our estimates of the skill premium (for skilled and highly-skilled workers, respectively, relative to semi and unskilled workers). Both of these are positive and statistically significant as expected, with $\alpha<\beta$. The coefficients $\gamma$ and $\delta$ are meant to capture a possible step increase in the economy-wide skill premium post-1990. We find no such increase - in fact, the estimated values for $\gamma$ and $\delta$ are negative, indicating a decline in the skill premium in the 1990s. (The interpretation of these coefficients is clouded somewhat by the presence of year dummies in the specification.)

With these estimates in hand, we split the remuneration series into a component that is the part that is predicted according to the specification above, and a component that represents the skill-adjusted remuneration level (the residual). In other words, real remuneration $=$ skill-upgrading $($ rem_pred $)+$ wage push $($ rem_resid $)$

One problem with this decomposition is that skill-upgrading may not be exogenous, and may respond to wage push. Imagine, for example, that unions push the wages of low-skilled workers above market-clearing levels. Then firms may respond by reducing the share of low-skilled employees in their workforce. In such a scenario, the rise in real remuneration is fully the consequence wage push, even though the mechanical decomposition carried out here will 
suggest otherwise. I will suggest below that this possibility is not quite consistent with the facts that we observe.

Figure 15 shows the trends in rem_pred and rem_resid for the manufacturing sector. We see a striking contrast in the behavior of the two series. Skill upgrading has been clearly an ongoing process since at least 1980. But the skill-adjusted (residual) component of the real remuneration series exhibits a distinct fall during the 1990s compared to the 1980s. In other words, once the effect of skill upgrading is taken out, labor costs in manufacturing appear to have become less onerous in the 1990s than they were in the 1980s. This makes it very unlikely that wage-push factors can account for the reduction in manufacturing employment during the 1990s - regardless of what one thinks of the level of labor costs in South Africa.

What of the possibility, mentioned previously, that skill upgrading itself is the consequence of a wage push? Even if partly true, it is hard to square the evidence in the remuneration series with this hypothesis. Note first that skill upgrading has been a steady and ongoing process - it does not just pick up in the 1990s. It is not clear why manufacturing employment would start to decline only in the 1990s if this were the main story. Second, a bit of economic theory helps. Consider the comparative static exercise where we shock employment by an exogenous backward shift in the labor supply curve (a "wage push"). If the series we observe in Figure 15 were the equilibrium responses to such a shock, we would expect to see an increase in skill upgrading (which we do see) and an increase in the residual (which we do not see). For the initial wage push to result in a lower skill-adjusted wage level in the new equilibrium, the labor demand curve would need to be positively sloped rather than negatively sloped. For these reasons, it seems implausible that rising wage costs were themselves the original source of the decline in manufacturing employment. 
The econometrics of structural change

I posit that output and employment in each sector of the economy responds to the following economic determinants:

- relative prices, measured by each sector's value added price index divided by the GDP deflator $\left(\ln p \_p g d p\right)$

- labor costs, measured by skill-adjusted real remuneration levels (lnrem_resid)

- skill-biased technological change, measured by the component of real remuneration that is "explained" by the skill composition of the workforce (lnrem_pred)

- $\quad$ total factor productivity growth $(\ln T F P)$.

I then run panel regressions for the following three dependent variables: (i) output (value added); (ii) total employment; and (iii) semi and unskilled employment. The panel consists of eight onedigit sectors - I exclude SIC 9, government services—over the 1980-2004 period. Each regression includes a full set of fixed effects for sectors and years.

Table 4 shows the results. The first two rows display the estimated coefficients on relative prices, allowing a different coefficient for the manufacturing sector (by entering a separate term that is interacted with a dummy for manufacturing). Where output is concerned, manufacturing shows no discernible difference from other sectors: a decrease in its relative prices reduces output in manufacturing by a virtually identical amount to that in other sectors on average. But with respect to employment, there are strong differences. We find that both total employment and unskilled employment is considerably more sensitive to changes in relative prices in manufacturing than they are elsewhere. And the effect is quantitatively quite strong: a 
ten percent reduction in relative prices is associated with an equivalent decline in employment (of roughly 10 percent).

Second, we find that while skill upgrading and labor costs are not associated strongly with changes in output, they have powerful effects on employment. Skill upgrading and skilladjusted labor costs both have the predicted, negative effects on employment, with the effect of skill upgrading particularly powerful on unskilled employment (which makes sense). The elasticity of employment with respect to (skill-adjusted) labor costs is around -0.6 and is very tightly estimated.

Finally, we find that productivity growth has asymmetric effects on output and employment. An increase in TFP boosts output (with an elasticity of 0.46 ) but reduces employment (with an elasticity of -0.19 for total employment and -0.21 for unskilled employment).

These results establish that patterns of structural change in South Africa can be understood within a parsimonious framework and using a relatively small number of economic determinants. Since this exercise yields encouraging econometric results, I next ask how well this framework explains the decline in manufacturing employment since the democratic transition in 1994 specifically. I do this by running a sector-level version of the specification in Table 4 (using data just from the manufacturing sector) and undertaking a "causal" decomposition of employment changes since 1994. Note that the sectoral regression for manufacturing yields coefficient estimates that are very close to those obtained in the panel specification (see the coefficients reported in Table 5). These regressions provide a remarkably good fit for the actual trends in employment (see Figure 16, which plots actual and fitted employment series for total and unskilled employment in manufacturing). Instrumental- 
variables estimation (using the external terms of trade and real exchange rate as instruments for $\left.\ln \_. p g d p\right)$ also produces very similar results.

The results of the decomposition exercise are reported in Table 5. Taking the 1980-90 period as the base, the decade since 1994 has witnessed a 14 log-point decline in total manufacturing employment. Meanwhile, relative prices for manufacturing have declined also by 14 log-points, skill-adjusted wage costs have fallen by 36 log-points, remuneration costs due to the skill composition of the workforce have increased by 32 log-points, and TFP has increased by 9 points. Applying these changes to the respective coefficient estimates for each explanatory variable, we get the causal decomposition reported at the bottom of the table. The bottom line that emerges is that the decline in relative price of manufacturing is the predominant cause of the fall in manufacturing employment. In fact, this factor alone accounts for more than 100 percent of the employment reduction.

Skill-biased technical change is the second most important contributor. TFP growth turns out to have made a comparatively small contribution to the decline in employment (around 11 percent), while the drop in skill-adjusted remuneration costs has operated in reverse, preventing manufacturing employment from falling even further.

In view of the starring role that the relative price of manufacturing plays in accounting for manufacturing's misfortunes, it is worth pausing to ask how real the decline in this price is, and what has caused it in the first place. I leave the second question to the next subsection, focusing here on the credibility of the fall of manufacturing's relative profitability. As I have discussed earlier, the decline in the terms of trade of manufacturing shows up in a variety of relative prices - including TFP-adjusted relative prices. Another comforting piece of evidence is that, as I will show below, standard economic variables do a reasonable job of explaining 
manufacturing's relative price, although a significant component of the decline remains unaccounted (attributed to a simple time trend). But a somewhat contradictory finding, reported by Aghion, Braun, and Fedderke (2006), is that markups in South African manufacturing are both high by international standards and have refused to come down since the 1990s. Indeed, gross operating surplus ratios in manufacturing (per unit of capital or as a share of value added) seem to have, if anything, increased over time. ${ }^{4}$ But there are reasons to worry about what these "markup" rates are measuring. One telling indicator is that measured markups rose significantly in footwear during the $1990 \mathrm{~s}$ - a sector that epitomizes hard times due to intense import competition from low-wage countries. In addition, there seems to have been even more striking increases in markup rates in sectors other than manufacturing. When one compares markups in manufacturing to those in, say, F.I.R.E., we observe a definite trend against manufacturing after 1990 (Figure 17). Indeed, if we take as our index of relative profitability the ratio of markups in manufacturing to markups in F.I.R.E., the trend that we observe is virtually identical to that when we use value-added prices (see Figure 17).

In sum, while measured markup rates throw out some important puzzles, the picture that one obtains after considering these various indicators is a consistent one: a post-1994 investordomestic or foreign — considering an investment in South Africa would have been far less likely (than s/he would have been in the 1980s) to commit resources to manufacturing, compared to banking, insurance, or other services oriented towards the home market.

Understanding the decline in manufacturing's relative price

\footnotetext{
${ }^{4}$ These data come from the same TIPS data base as the labor and output statistics used above. Aghion et al. use additional data sources from UNIDO and published company balance sheets in their international comparisons.
} 
Why did relative profitability in manufacturing decline in the 1990s? As discussed earlier, one candidate is intensified import competition. But other factors, including the real exchange rate and the terms of trade, may have played a role as well. Table 7 presents the results of an econometric attempt to model the behavior of manufacturing's relative price. The independent variables included are the terms of trade, the real exchange rate, import penetration, and a time trend. The dependent variable is the (log of the) value-added price of manufacturing divided by the GDP deflator ( $\ln p \_g d p$ ). As Figure 18 shows, the model does a decent job of tracking the in-sample behavior of this relative price and its decline over time. As expected, import penetration enters with a negative and statistically significant coefficient. The estimated coefficient on the real exchange rate is negative and significant as well, indicating that a real appreciation worsens the relative profitability of manufacturing (with an elasticity of 0.1 ). To the extent that the real exchange rate approximates the price of non-tradables relative to tradables, the inverse relationship between the real exchange rate and manufacturing's relative price reflects the fact that manufactures are the quintessential tradables. The econometrics confirm that the level (and also presumably the volatility) of the real exchange rate is a significant determinant of the health of manufacturing. The external terms of trade do not enter significantly, but that could well be the result of the fact that we are controlling for the real exchange rate separately. Since South Africa is a natural resource exporter, the main channel through which the terms of trade affects the relative profitability of manufacturing would be through the real exchange rate. Finally, the regression indicates that there is a strong downward time trend in manufacturing's relative price even after we control for these other influences.

Table 8 reports the results of a decomposition exercise using the regression coefficients just discussed. Once again, we compare the decade after 1994 with the baseline of 1980-90. The 
relative price of manufacturing has declined by 14 log-points between these two periods. The main message that comes across from the decomposition is that the bulk of this decline is “explained" by the time trend-i.e., remains unexplained by the economic determinants included in the regression. Import competition itself accounts for about a quarter of the decline in profitability. The real exchange rate, which stood at a more depreciated level post-1994, makes a positive contribution to manufacturing's relative profitability. In fact, the depreciation of the real exchange rate seems to have offset about four-fifths of the adverse effect of import competition. A more depreciated exchange rate presumably would have been even better for the health of manufacturing.

In order to examine the effect of international trade on manufactures more closely, I have also looked at the relationship between imports and export ratios and relative output prices across twenty-eight individual manufacturing subsectors (in a fixed effects framework with year and subsector dummies). I find that an increase in import penetration has a strong negative effect on a manufacturing subsector's relative price, while an increase in exports has a less strong but still statistically significant positive effect (Table 9, col. 1). These results confirm at a more disaggregated level that manufacturing's profitability is strongly linked to trade competition and performance. They also confirm that the causality runs from trade to prices, rather than vice versa. (If higher import penetration were the result of higher prices charged by domestic suppliers, the correlation between imports and prices would be positive rather than negative.) Looking at employment consequences across manufacturing subsectors directly, we similarly find that import penetration has adverse effects on employment while exports have a positive effect (Table 9, col. 2). ${ }^{5}$

\footnotetext{
${ }^{5}$ It is the case that the trade-induced decline in manufacturing employment has been partially offset by an increase in employment in trade-related services, particularly wholesale and retail trade (SIC 6). But since wholesale and
} 
But what do we make of the large unexplained time trend in manufacturing's relative profitability? My speculative answer is that the simple regression model above does a poor job of capturing the full effect of trade openness and globalization on manufacturing profitability. Caught between more advanced countries at the high end and China at the low end, it seems safe to assume that South African producers have had a rough ride during the 1990s.

\section{$\underline{\text { V. Concluding remarks }}$}

The disappointing growth and employment trajectory of the South African economy since its democratic transition is best understood as a consequence of the under-performance of its non-resource tradables sector, and of manufacturing in particular. Had the South African manufacturing sector expanded rapidly, economic growth would have been higher and far more jobs would have been created for the relatively unskilled. In principle, jobs can also be created by cutting the cost of labor. But reducing unemployment by expanding the capacity of the economy to provide high-productivity, high-wage jobs for the unemployed is a far better strategy. Therefore, the health and vitality of the formal manufacturing sector has to be at the core of any strategy of shared growth.

As I have shown in this paper, the behavior of South Africa's manufacturing sector is well explained by standard economic determinants. Prices, costs, and productivity are the main drivers of manufacturing production and employment. Therefore putting manufacturing on a permanently steeper trajectory will necessitate working on these same levers. In particular, it will require reversing the decline in relative profitability which the econometrics tells us has been the primary culprit for the sector's misfortunes.

retail trade is considerably more skill intensive compared to manufacturing, the net job loss for unskilled workers has still been considerable. 
This diagnosis has clear implications for both macro and micro policies. At the macro level, it requires a combination of monetary and fiscal policies that will allow the South African Reserve Bank (SARB) to run a modified inflation targeting framework which allows considerations of competitiveness to affect its decision-making. Putting it more bluntly, SARB will need to develop views about the equilibrium real exchange rate--where "equilibrium" refers to satisfactory outcomes in terms of tradable output and employment--and steer exchange rates accordingly. Cross-national evidence indicates that intervention and other monetary policies can affect the level of the real exchange rate over the medium term, with important consequences for economic growth (Frankel et al. 2006). Without a relatively stable and competitive exchange rate, it will be extremely difficult to coax entrepreneurs to make sizable investments in manufacturing.

On the micro front, the need is for more coherent and better coordinated industrial policies targeted at what Hausmann and I have called "self-discovery" (Hausmann and Rodrik 2003). The objective here is to encourage private investment and entrepreneurship in new areas where South Africa can develop comparative advantage. In the absence of pro-active policies, such new investments do not necessarily materialize. South Africa is already moving in this direction in the context of ASGI-SA, and the Department of Trade and Industry's (DTI) recent document “A National Industrial Policy Framework” outlines an ambitious strategy for making the approach operational. Two things are needed to ensure that this strategy will become a success. First, greater discipline in targeting policy interventions on plausible, identified sources of market failures instead of on vague, and economically meaningless objectives (such as greater domestic "beneficiation" or higher value added). Second, a better institutional structure to 
ensure (a) political leadership and coordination at the top, and (b) strategic collaboration at the bottom with business and other stakeholders (Rodrik 2004).

The good news is that the objectives of macroeconomic stability, economic growth, and social equity all require the same fundamental structural shift in the South African economy: an expanded non-resource tradables sector. Together, the micro and macro policies reviewed above can put South Africa on a path of structural transformation that invigorates non-resource tradables, raises economic growth, and reduces unemployment. 


\section{REFERENCES}

Aghion, Philippe, Mathias Braun, and Johannes Fedderke, "Markups and Growth in South Africa," CID South Africa Project Report, Harvard University, July 2006.

Banerjee, Abhijit, Sebastian Galiani, Jim Levinsohn, and Ingrid Woolard, "Why is Unemployment So High in South Africa?" CID South Africa Project Report, Harvard University, July 2006.

Bertrand, Marianne, Sendhil Mullainathan and Douglas Miller, "Public Policy and Extended Families: Evidence from Pensions in South Africa," The World Bank Economic Review, vol. 17, no. 1, 2003, 27-50.

Charmes, Jacques, "Informal sector, poverty and gender: A review of empirical evidence," background paper for World Development Report 2001, Centre of Economics and Ethics for Environment and Development, University of Versailles-St Quentin en Yvelines, 2000.

du Plessis, Stan, and Ben Smit, "Economic growth in South Africa since 1994," University of Stellenbosch, 2006.

Edwards, Lawrence, and Robert Lawrence, "South African Trade Policy Matters: Trade Performance \& Trade Policy," CID South Africa Project Report, Harvard University, July 2006.

Fedderke, Johannes, "Towards an understanding of the growth absence: reviewing the evidence that can account for the poor growth performance of the South African economy," Johannesburg, WITS University and ERSA, 2002.

Frankel, Jeffrey, Ricardo Hausmann, Ben Smits, and Federico Sturzenegger, "South Africa Project Macro Report: Managing Capital Flows," CID South Africa Project Report, Harvard University, July 2006.

Hall, Robert E., and Charles I. Jones, "Why Do Some Countries Produce So Much More Output Per Worker Than Others?," The Quarterly Journal of Economics, vol. 114(1), pages 83-116, February 1999.

Hartzenberg, Trudi, and John Stuart, "South Africa's Growth Performance since 1960: A Legacy of Inequality and Exclusion," Prepared for AERC Growth Project, School of Economics, University of Cape Town, May 2002.

Hausmann, Ricardo, and Dani Rodrik, "Economic Development as Self-Discovery," Journal of Development Economics, vol. 72, December 2003.

Hausmann, Ricardo, Jason Hwang, and Dani Rodrik, "What You Export Matters," Harvard University, May 2006. 
Hirsch, Alan, Season of Hope: Economic Reform under Mandela and Mbeki, University of KwaZulu-Natal Press/IDRC, 2005.

Kingdon, G. and J. Knight. "Unemployment in South Africa: The Nature of the Beast", World Development, 32, No. 3, March, 2004.

Leibbrandt, Murray, James Levinsohn, and Justin McCrary, "Incomes in South Africa since the Fall of Apartheid,” NBER Working Paper No. 11384, May 2005.

Rancchod, V., "Household Responses to Adverse Income Shocks," University of Michigan, draft, 2006.

Rodrik, Dani, "Industrial Policy for the Twenty-First Century," Harvard University, September 2004. 
Figure 1

Investment and growth

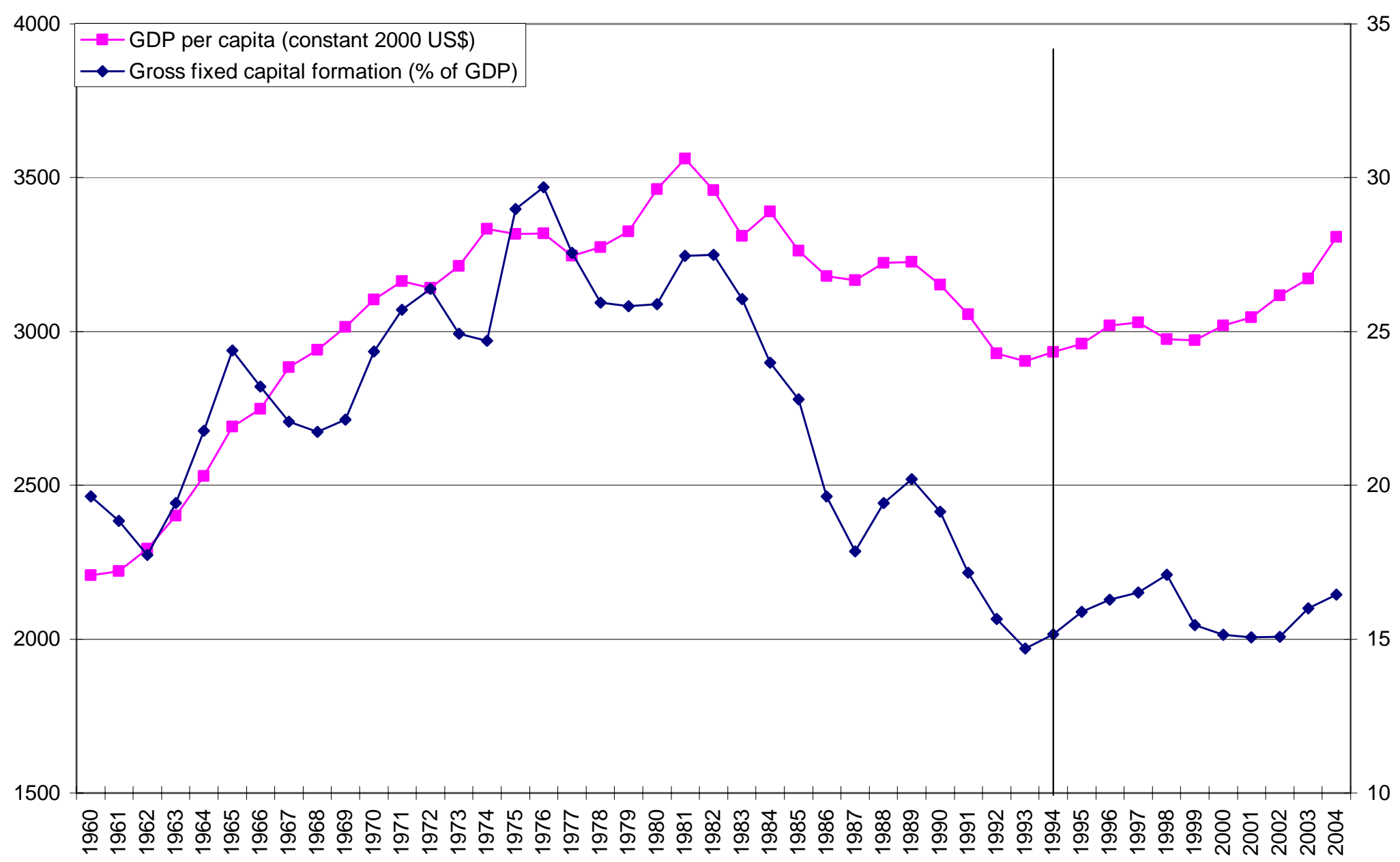


Figure 2

Unemployment rates (c. 2002)

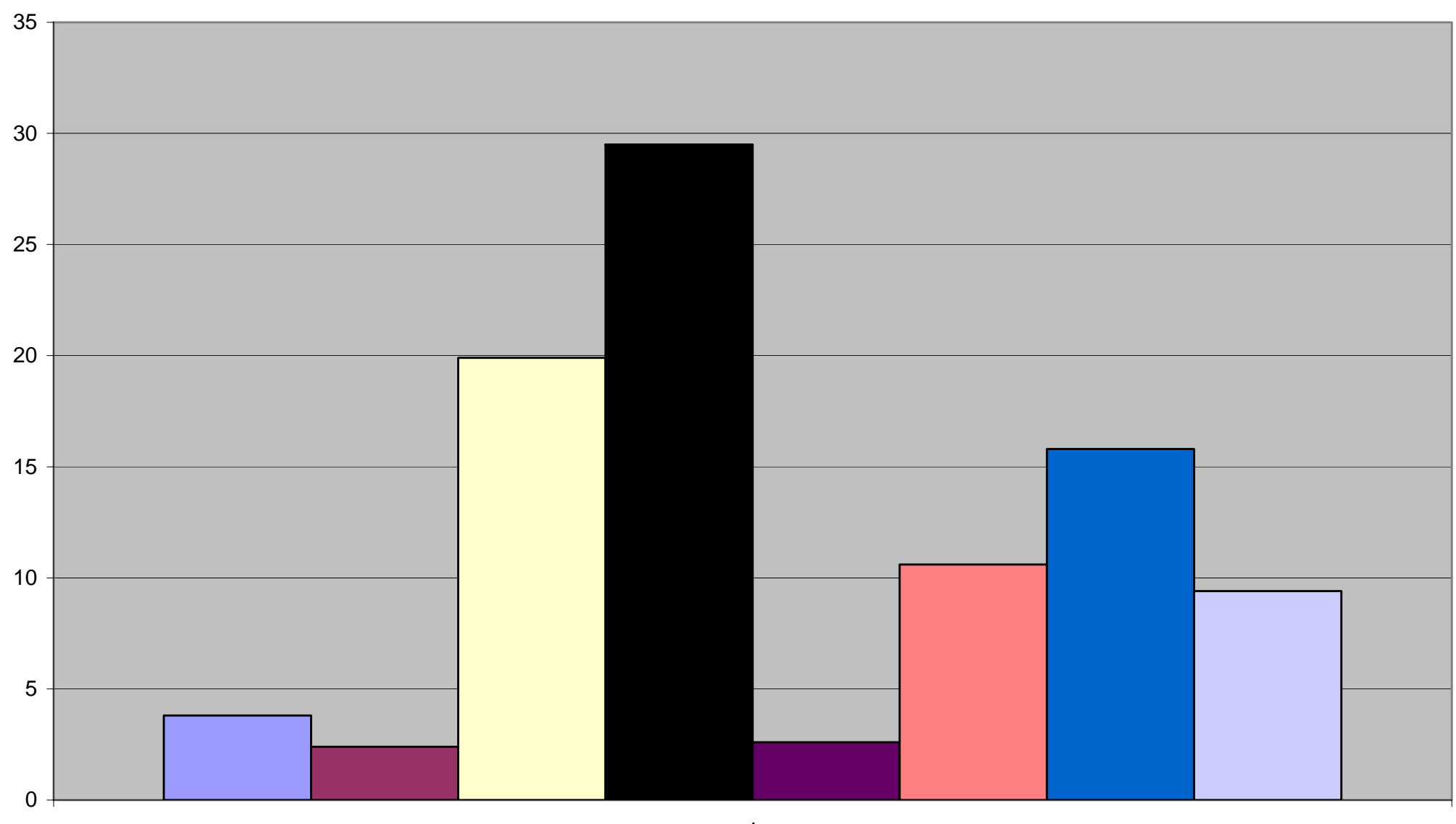

1

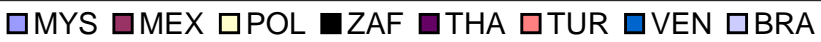


Table 1

A snapshot in 1988 (US=1)

\begin{tabular}{|c|c|c|c|c|c|}
\hline & $\mathrm{Y} / \mathrm{L}$ & $(\mathrm{K} / \mathrm{Y})^{\wedge} \mathrm{a}$ & $\mathrm{H} / \mathrm{L}$ & A & $\begin{array}{l}\text { mining } \\
\text { share of } \\
\text { GDP }\end{array}$ \\
\hline ZAF & 0.25 & 0.959 & 0.568 & 0.46 & 0.111 \\
\hline MYS & 0.267 & 1.004 & 0.592 & 0.45 & 0.103 \\
\hline
\end{tabular}

Source: Hall and Jones (1999) 
Figure 3

\section{Manufacturing employment (as share of labor force)}

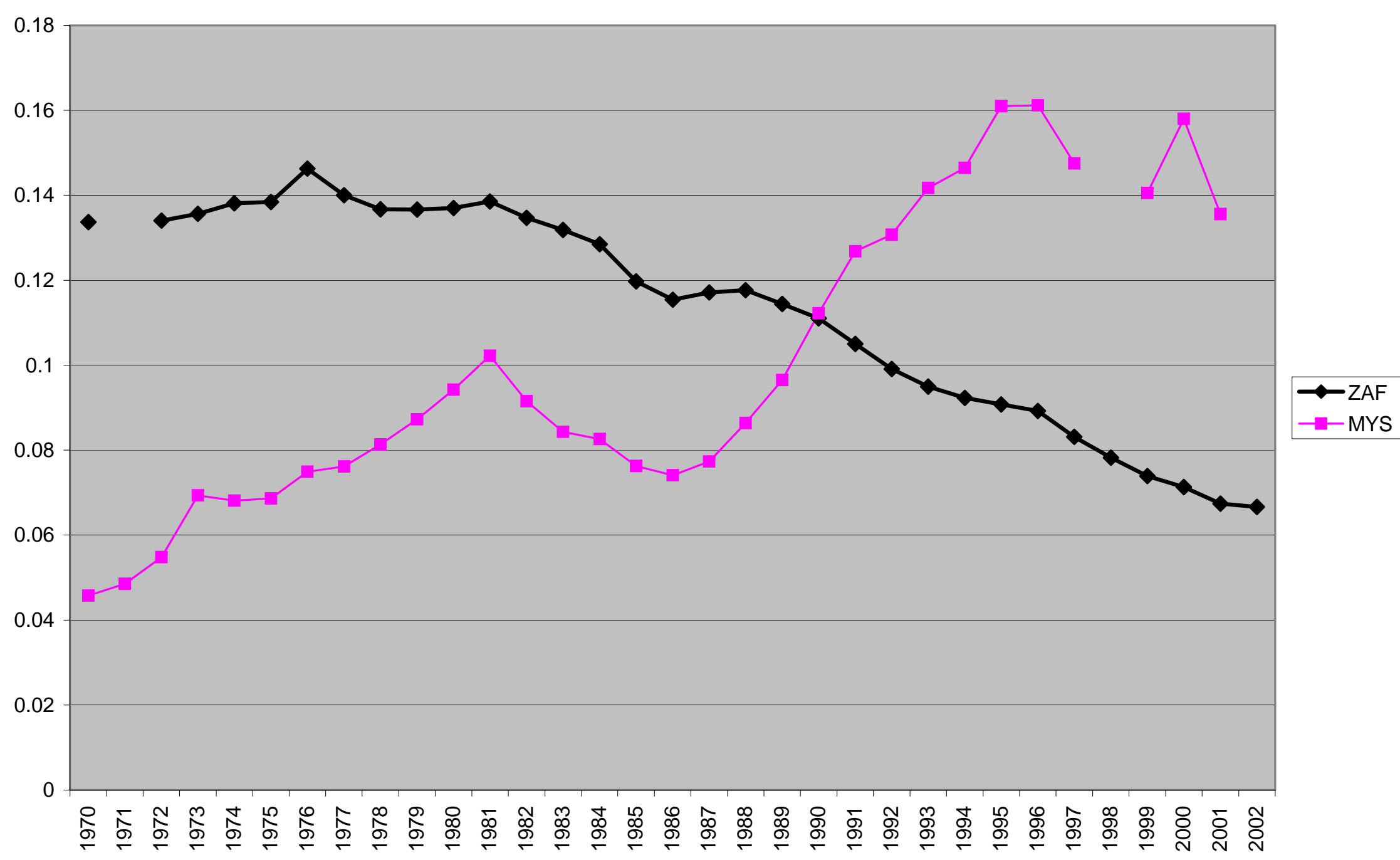


Figure 4

ZAF-MYS comparisons (2004)

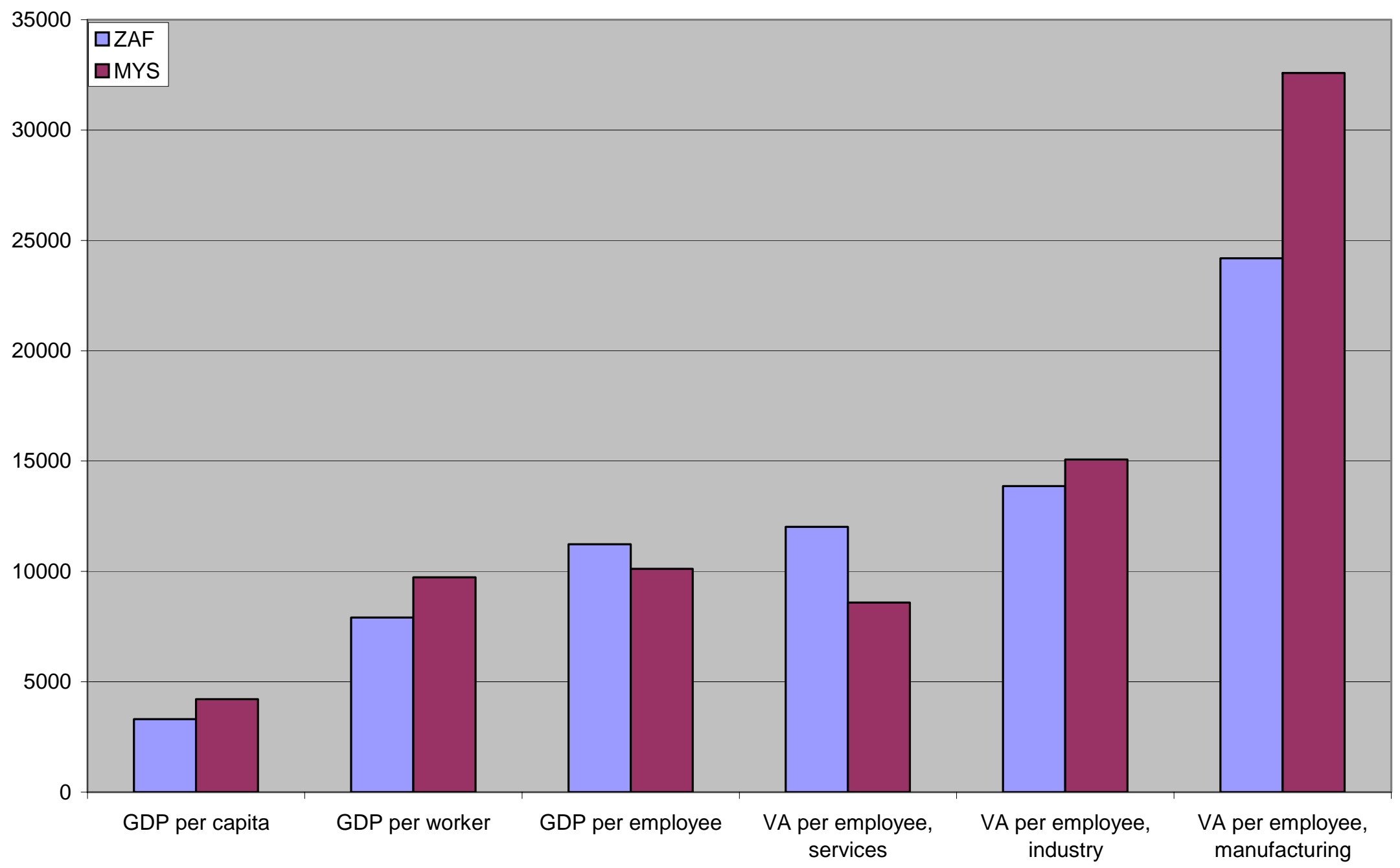


Figure 5

\section{Income level of exports (EXPY)}

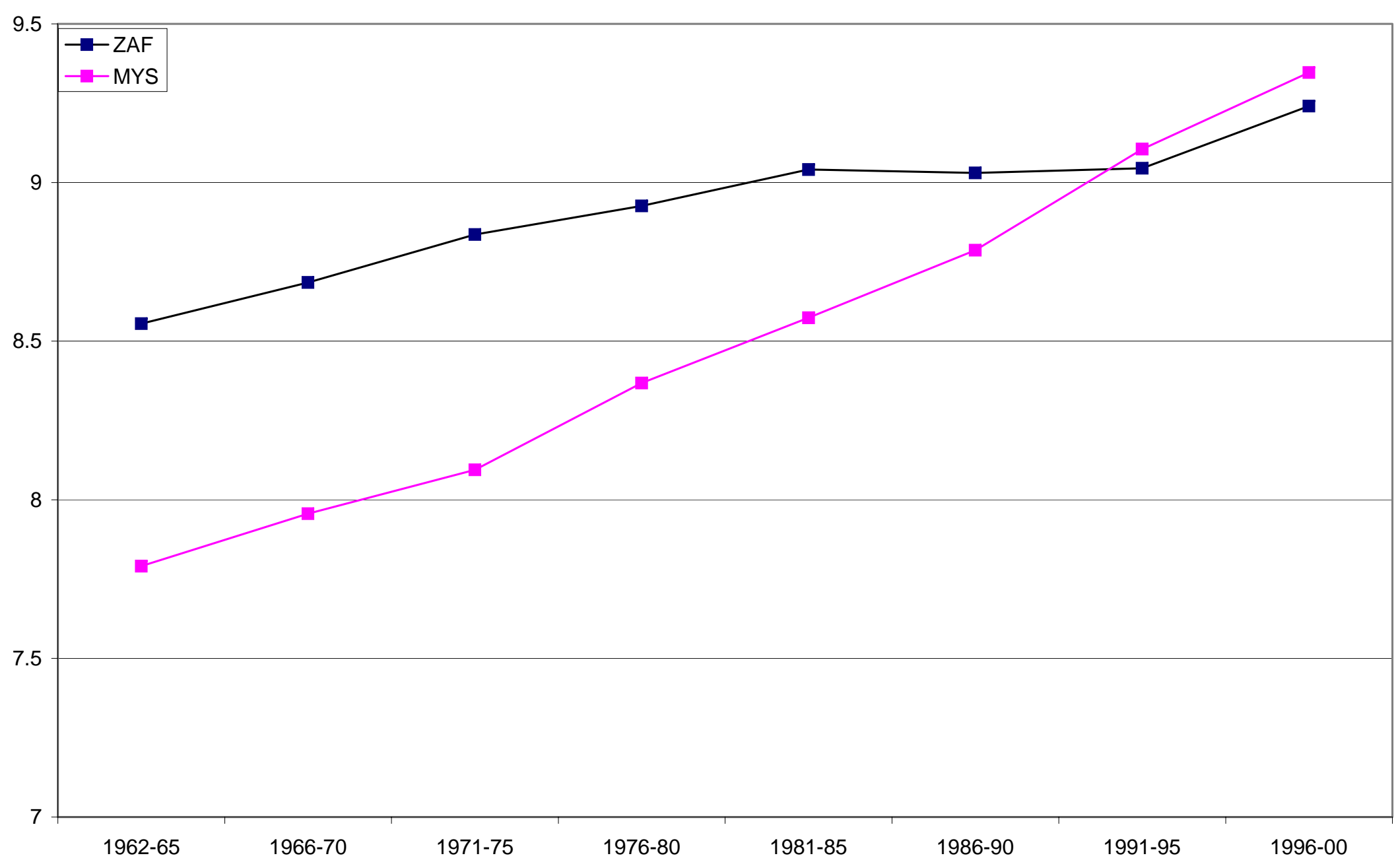

Note: This measure of the sophistication of export baskets comes from Hausmann et al. (2006). 
- Early 1970s: EPZs combined with restrictions on unionism to attract MNEs

- Early 1980s: heavy industrialization strategy focusing on trade protection, bumiputera-ownership, and public enterprise

- Recession in mid-1980s, followed by privatization

- Late 1980s: trade liberalization plus substantial incentives to investment and exports (including on "priority products")

- Very little rise in skill intensity, even though manufacturing takes off

- Early 1990s: Focus on training and skills

- Incentives increasingly tied to domestic sourcing of inputs 


\section{Figure 6}

Total employment, by skill category

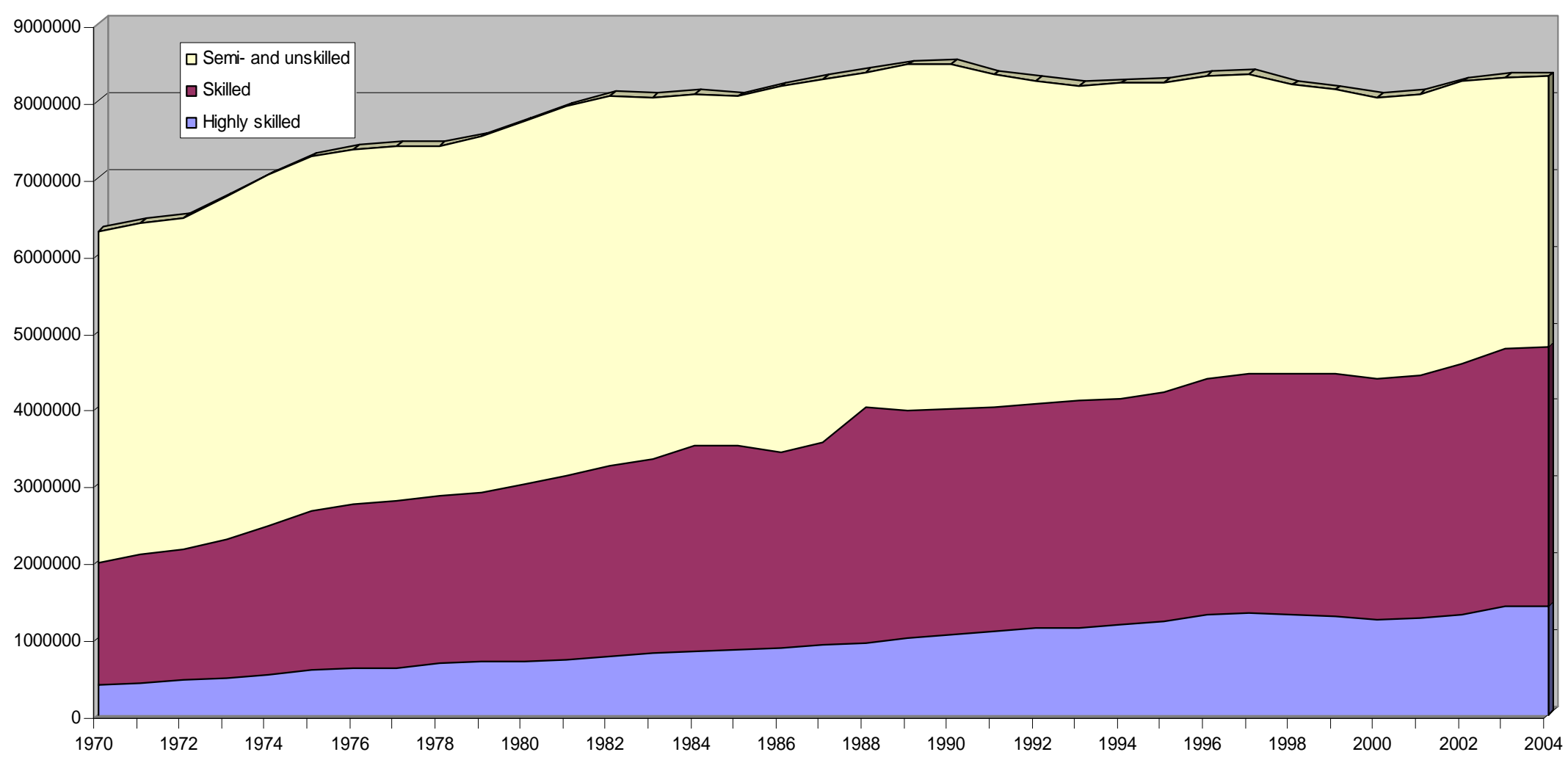




\section{Figure 7}

Employment shares: all skill categories

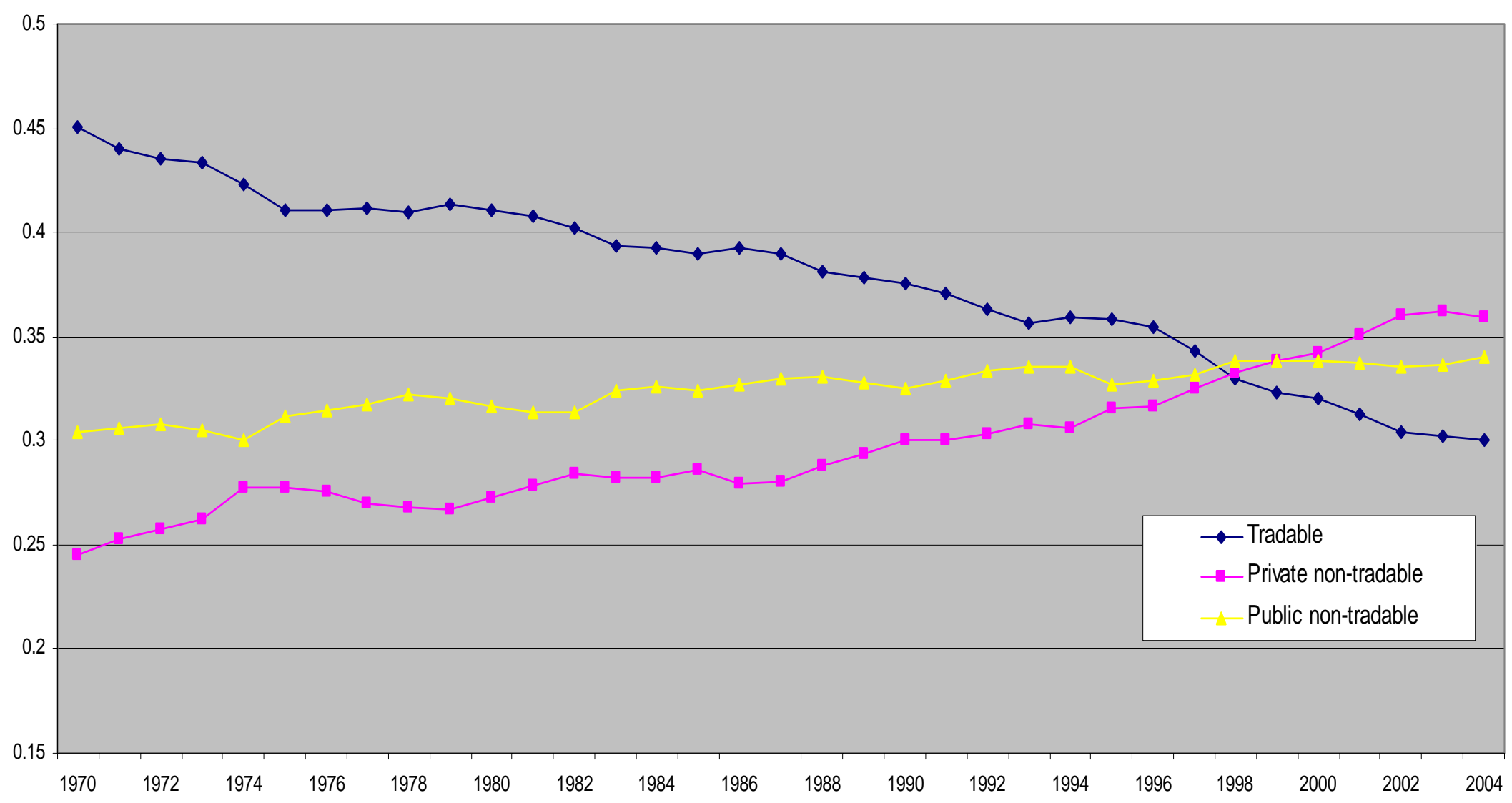


Figure 8

Low skill intensity by sectors: Shares of low and unkilled workers in sectoral employment

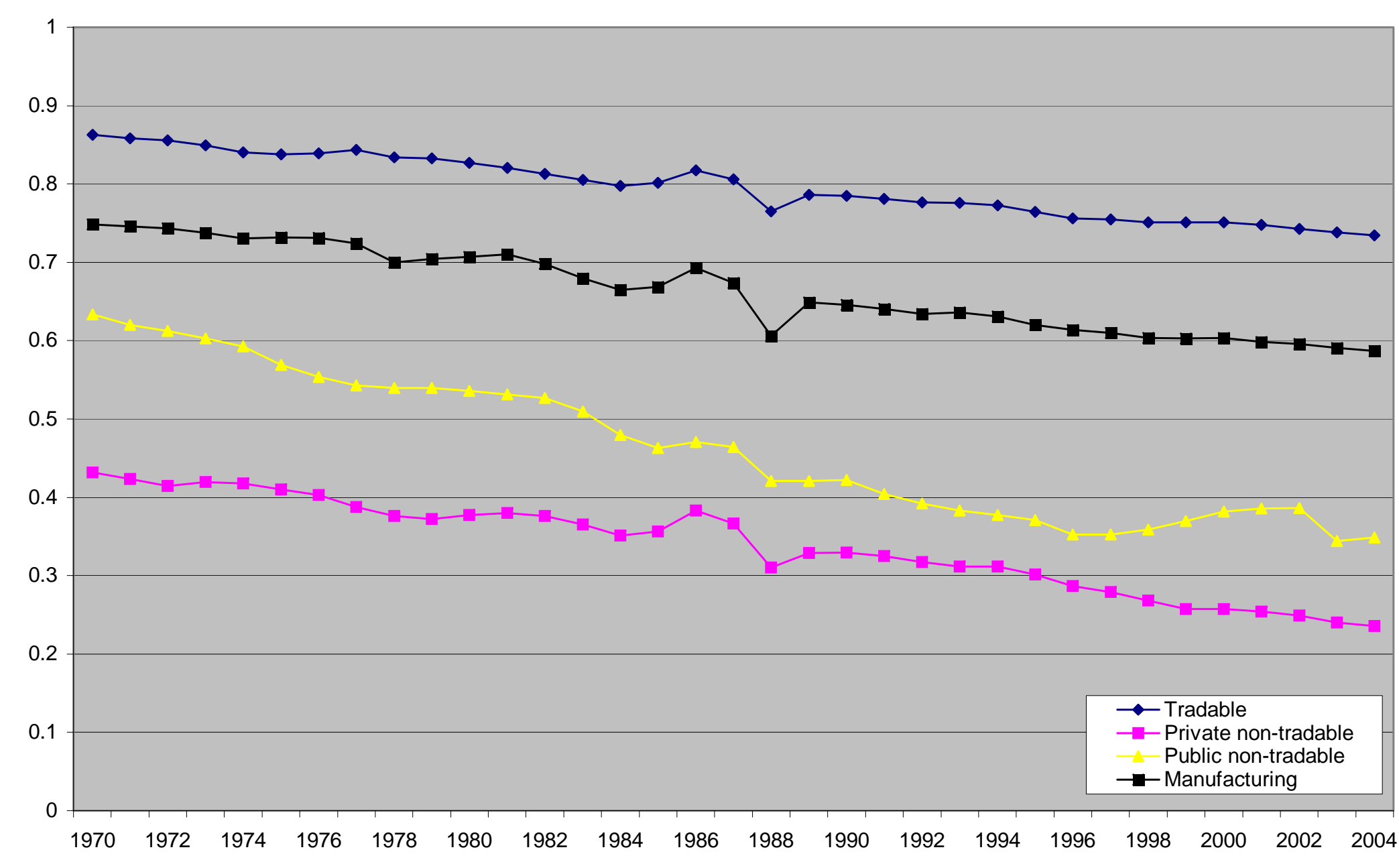


Figure 9

Change in employment versus initial low-skill intensity, by manufacturing subsectors, 19702004 (annual average percent changes)

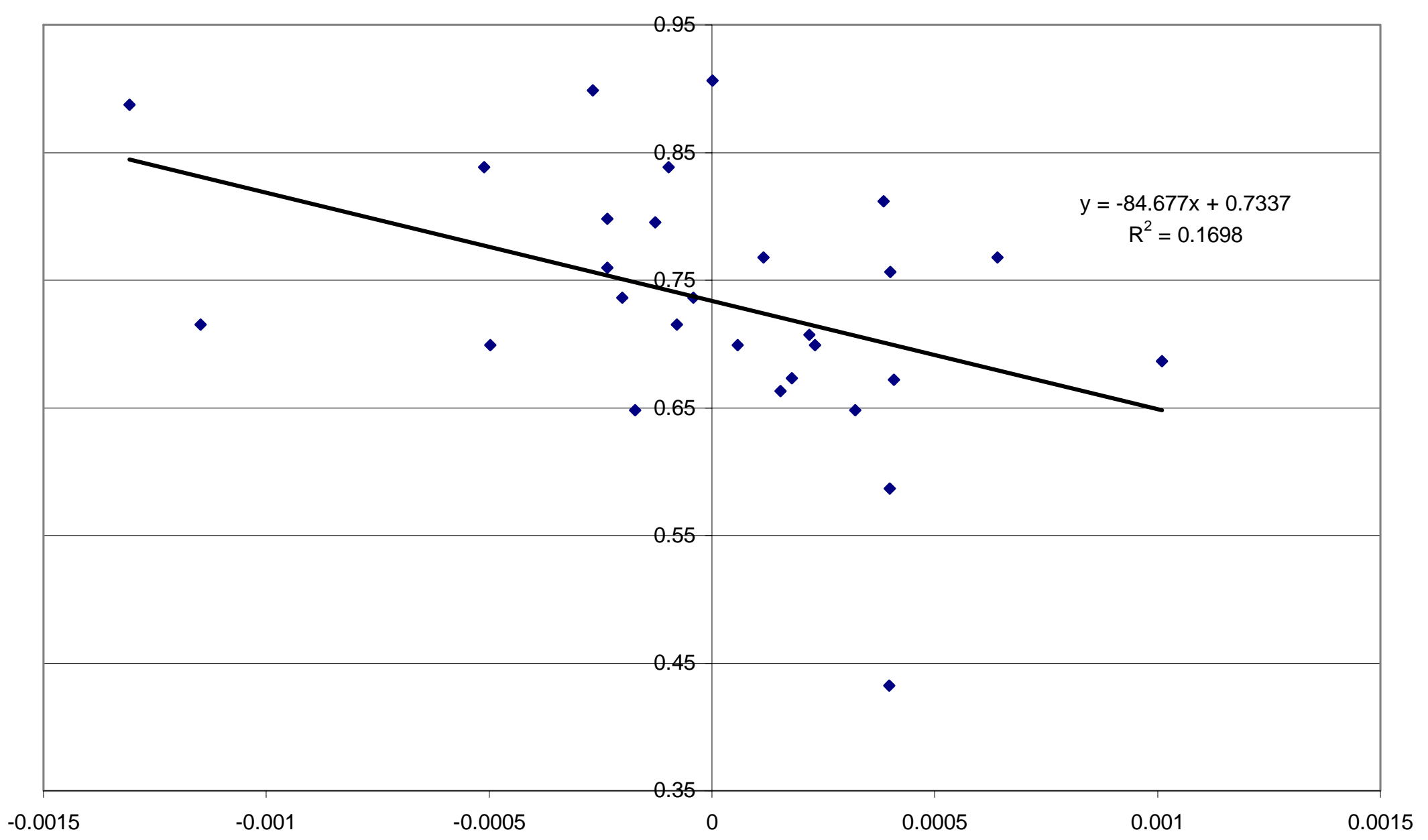


Figure 10

\section{Real capital per worker (Rm in 2000 prices)}

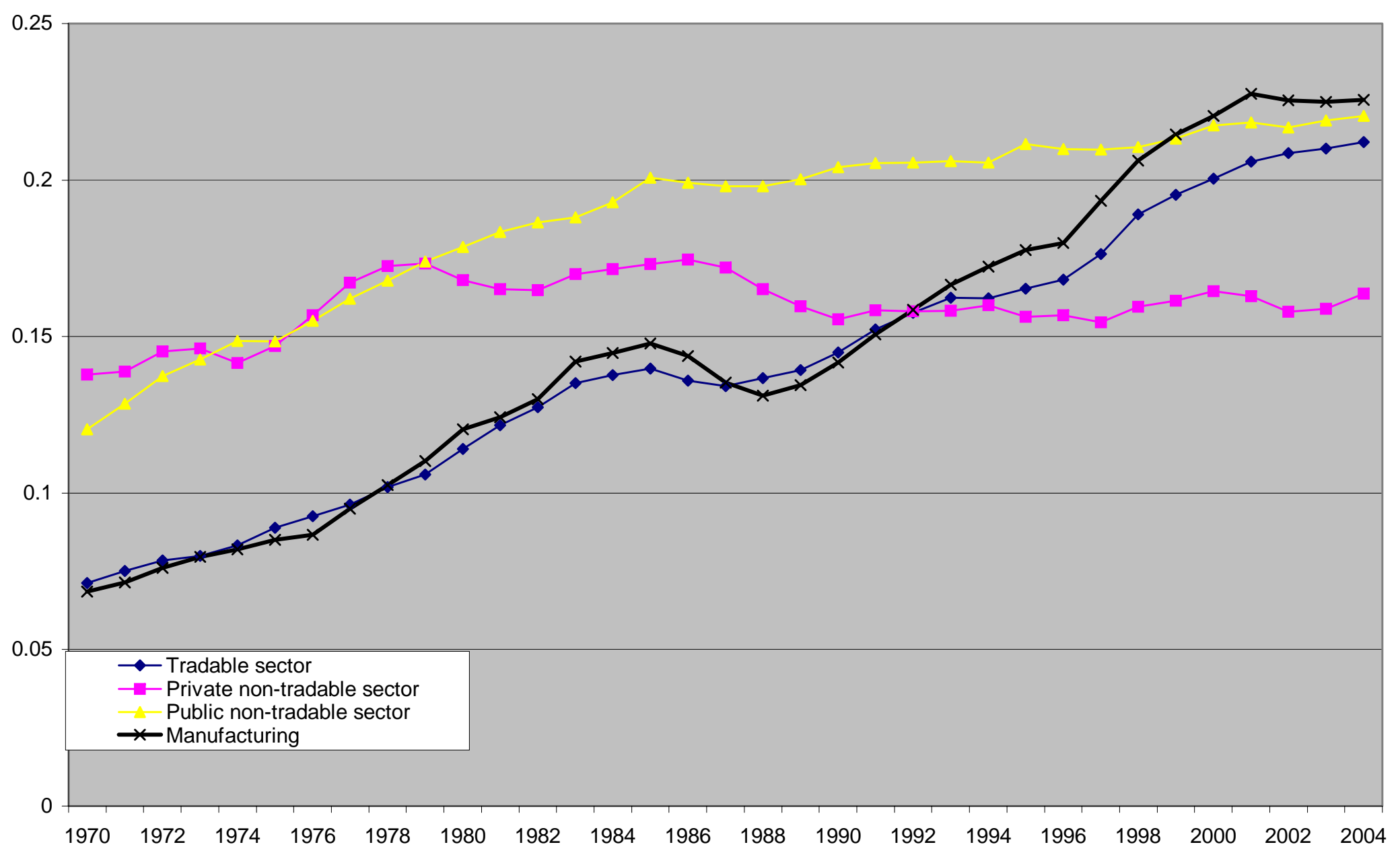


Table 2

\begin{tabular}{|l|l|l|}
\hline & $\begin{array}{l}\text { Urban } \\
\text { unemployment rate } \\
\text { (1990s) }\end{array}$ & $\begin{array}{l}\text { Informal } \\
\text { employment as a } \\
\text { share on non-agr. } \\
\text { employment) }\end{array}$ \\
\hline $\begin{array}{l}\text { South } \\
\text { Africa }\end{array}$ & 29.3 & 18.9 \\
\hline $\begin{array}{l}\text { Other sub- } \\
\text { Saharan } \\
\text { Africa }\end{array}$ & 16.0 & 74.8 \\
\hline $\begin{array}{l}\text { Latin } \\
\text { America }\end{array}$ & 8.1 & 56.9 \\
\hline Asia & 5.3 & 63.0 \\
\hline
\end{tabular}

Source: Charmes (2000) via Kingdon and Knight (2003) 
Figure 11

\section{Manufacturing employment and relative output prices}

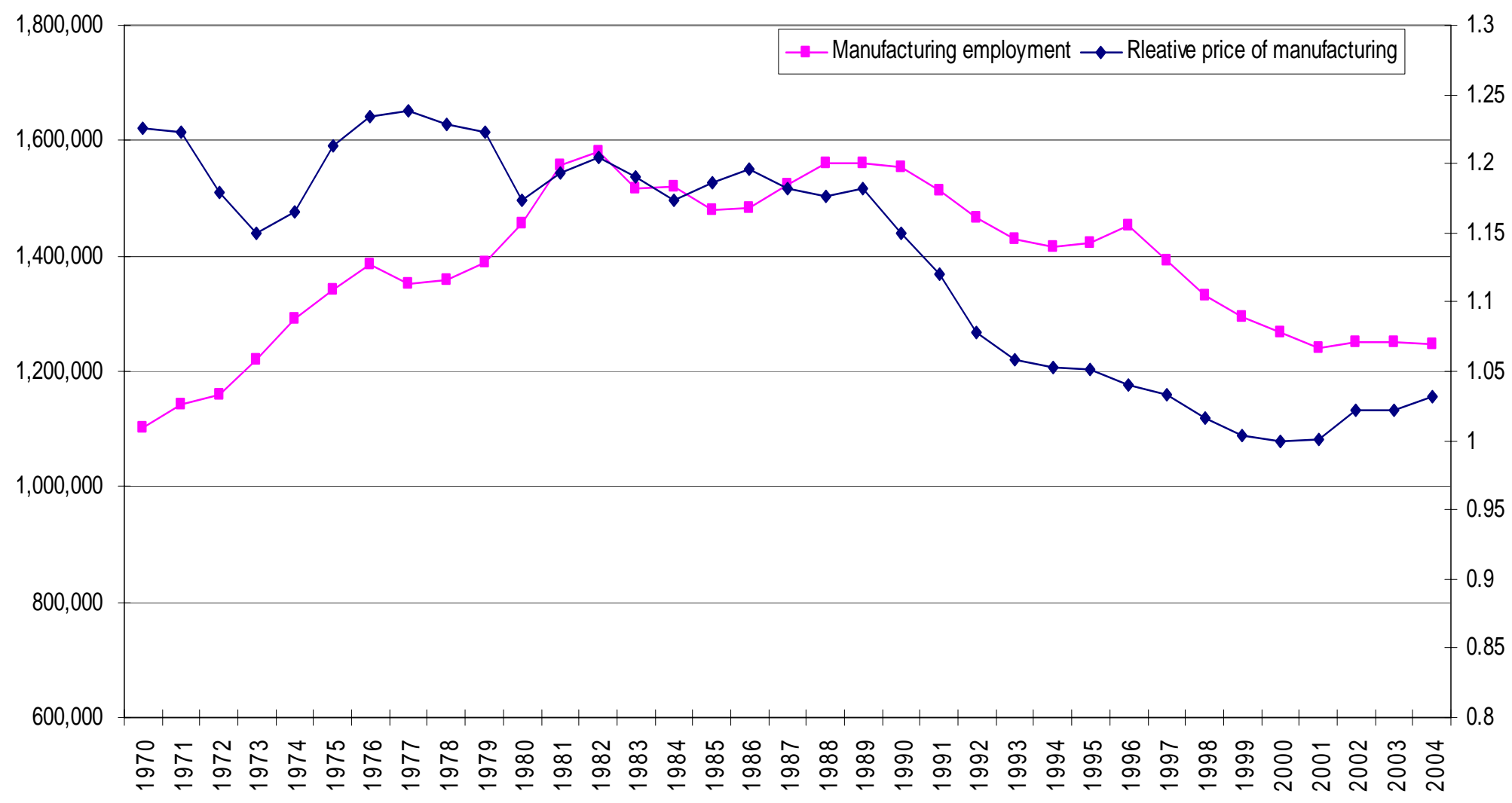


Figure 12

TFP-adjusted relative prices for manufacturing

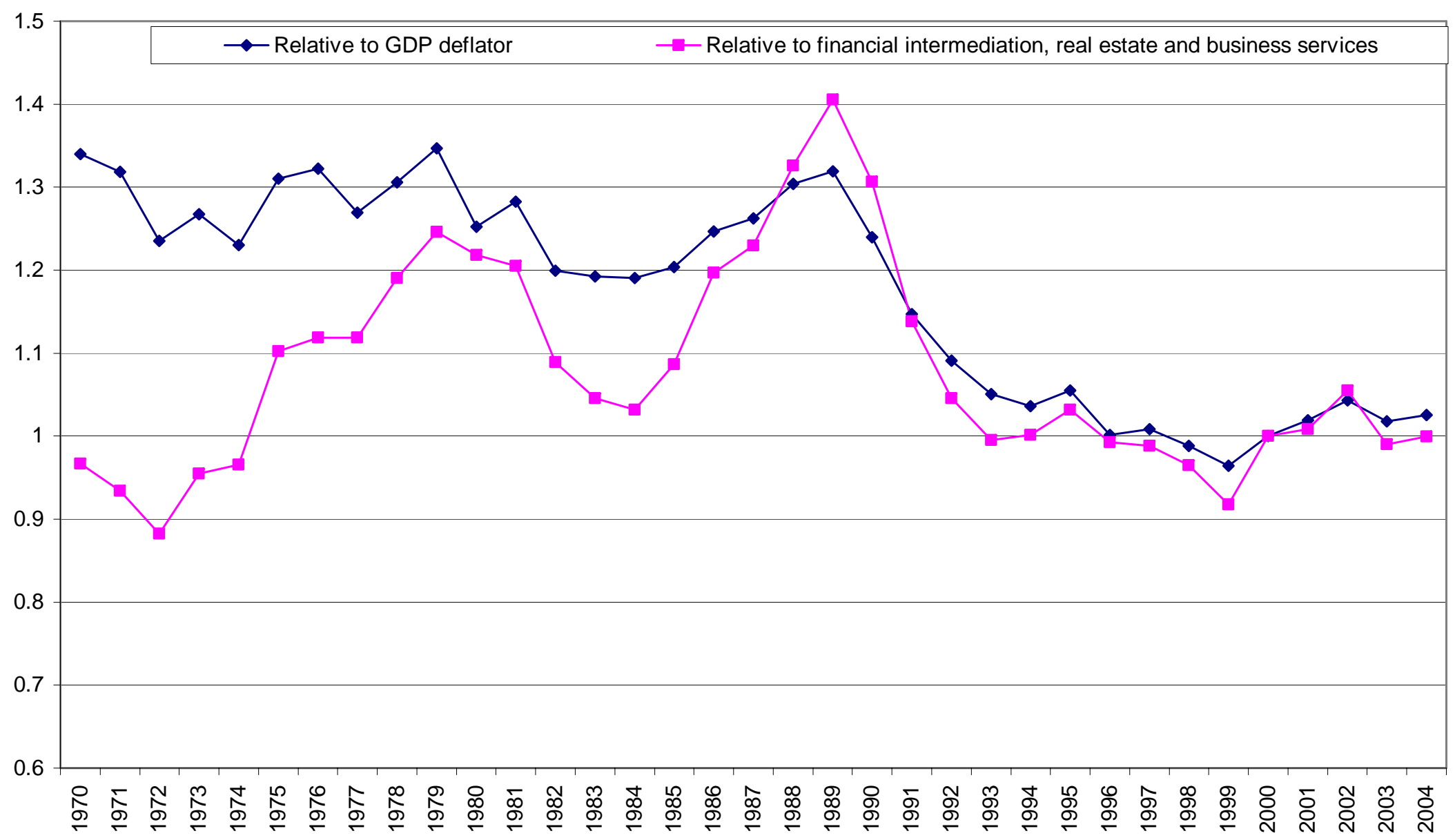


Figure 13

\section{Manufacturing employment and import penetration}

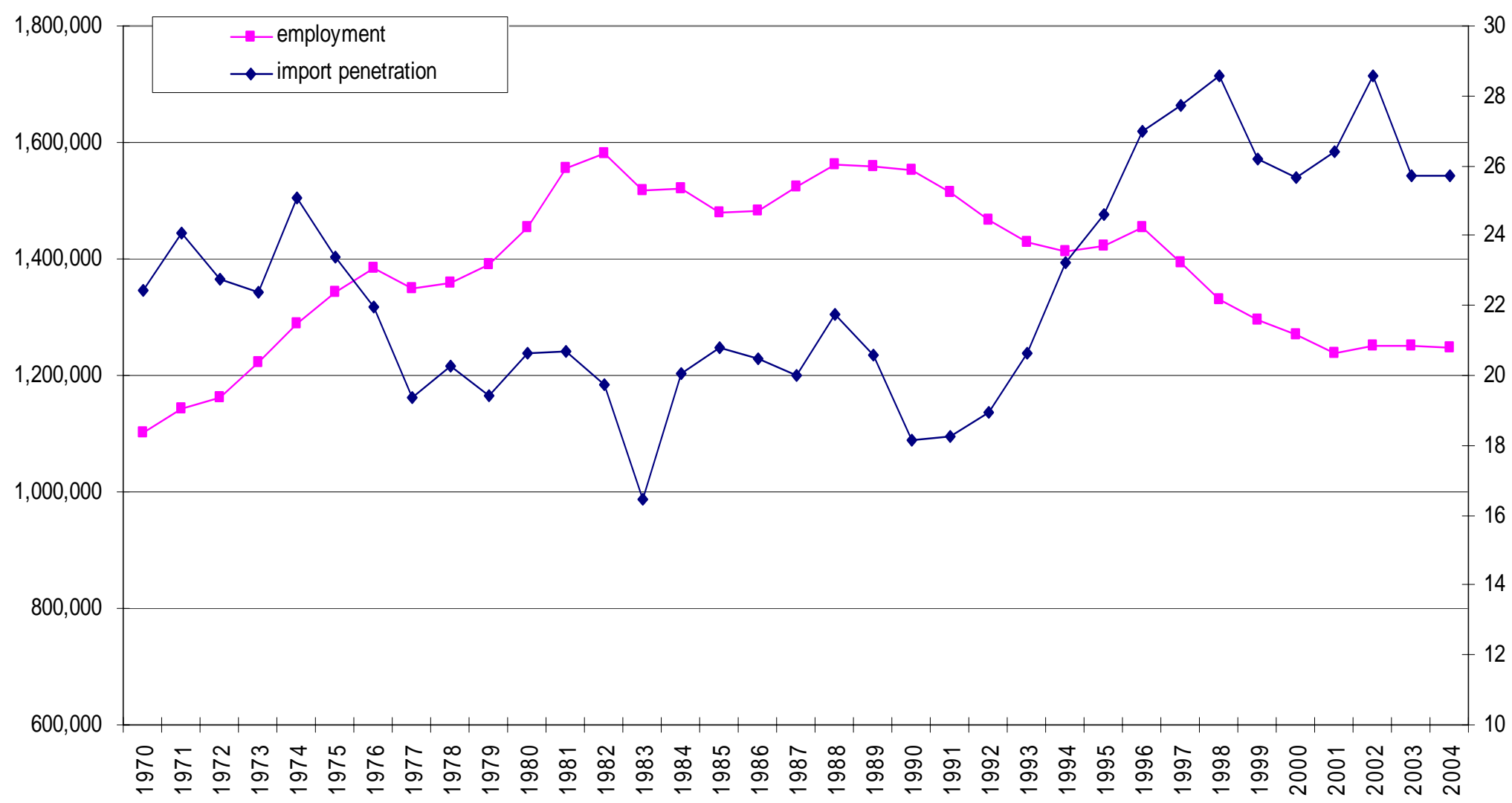


Figure 14

\section{Manufacturing employment and real remuneration}

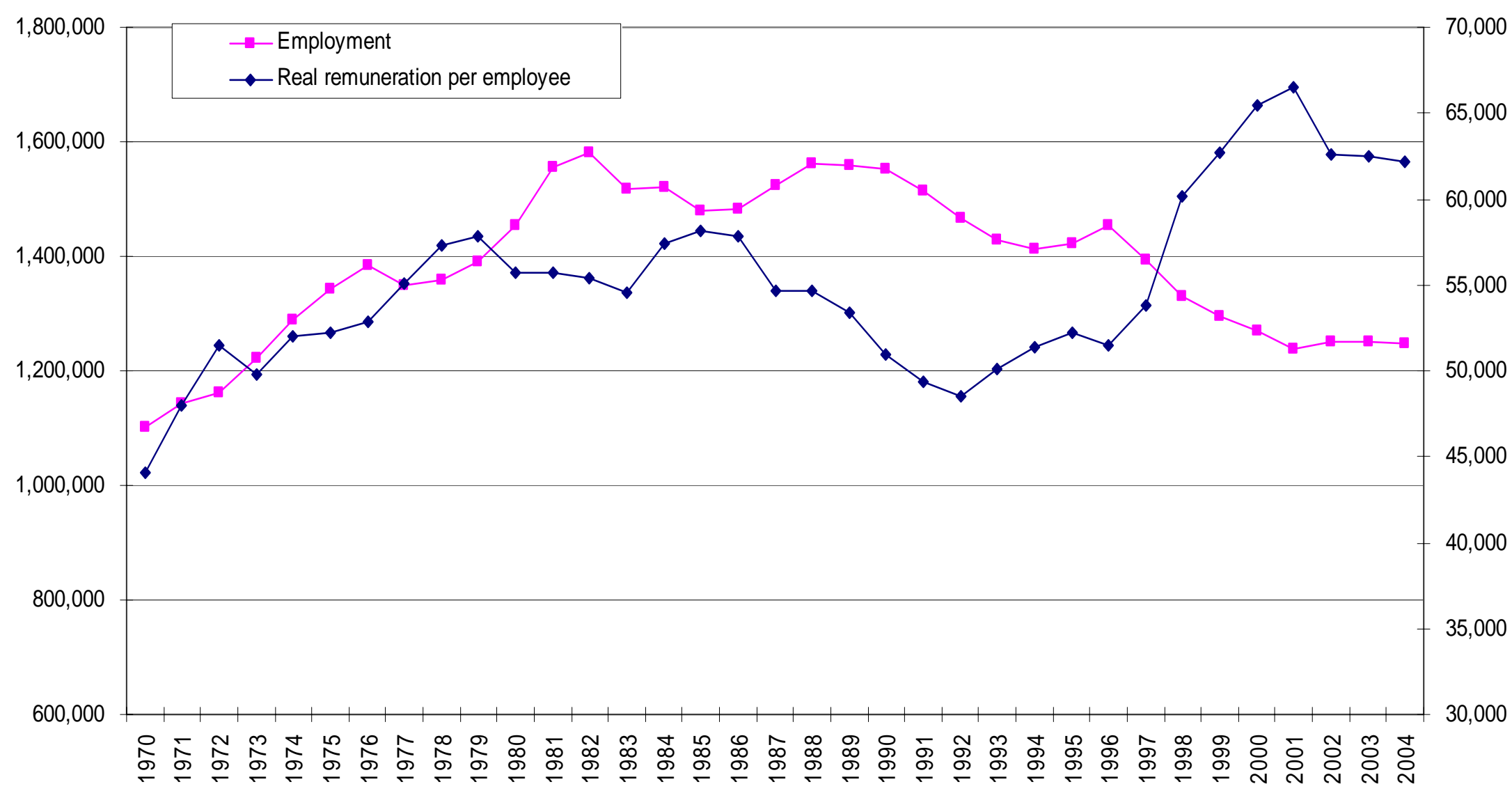


Table 3

\begin{tabular}{|l|c|c|c|c|}
\hline & $\alpha$ & $\beta$ & $\gamma$ & $\delta$ \\
\hline coeff. & 4.36 & 11.64 & -0.51 & -2.59 \\
\hline t-stat & 4.76 & 10.33 & -2.98 & -4.21 \\
\hline
\end{tabular}

Estimated across nine 1-digit industries over 1980-2004, with a full set of year and sector dummies. 
Figure 15
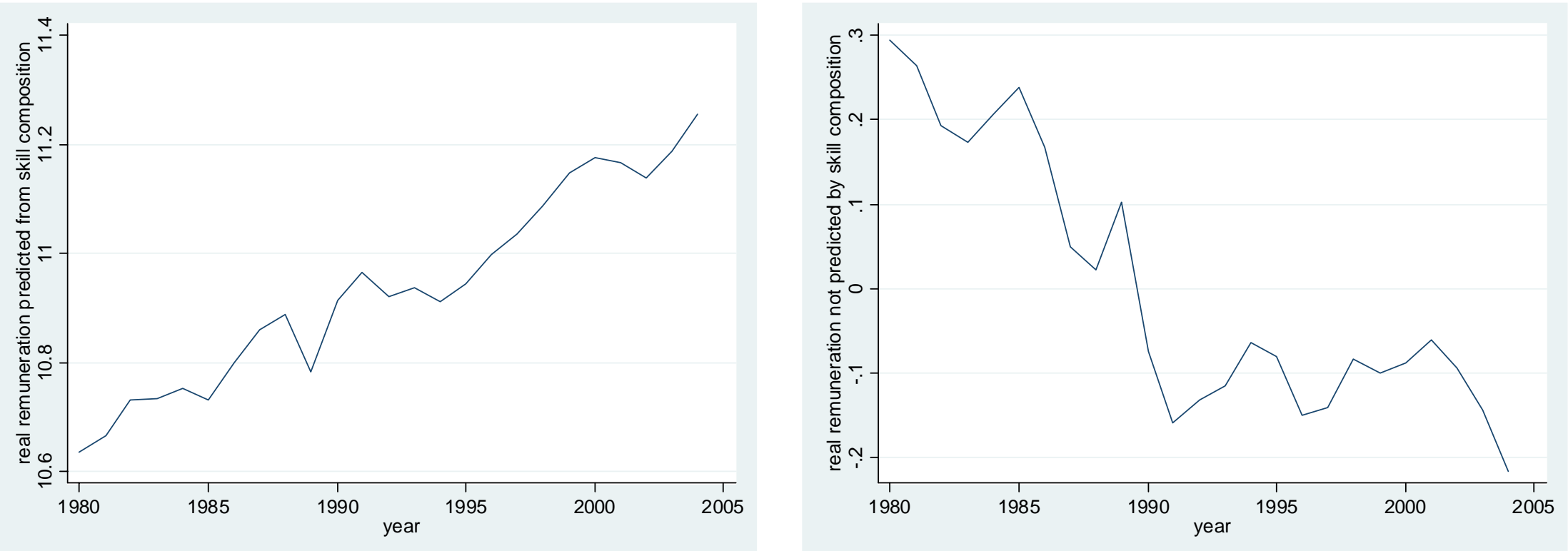

skill upgrading (rem_predicted)

"wage push"

(rem_residual) 
Table 4

\begin{tabular}{|c|c|c|c|}
\hline & depend & dent variable ( & n logs) \\
\hline & value added & employment & $\begin{array}{c}\text { unskilled } \\
\text { employment }\end{array}$ \\
\hline Inp_pgdp & $\begin{array}{r}0.35 \\
4.45\end{array}$ & $\begin{array}{r}0.21 \\
1.74\end{array}$ & $\begin{array}{r}-0.21 \\
-2.04\end{array}$ \\
\hline Inp_pgdp $x$ & & & \\
\hline manufacturing & $\begin{array}{r}-0.04 \\
-0.13\end{array}$ & $\begin{array}{r}1.24 \\
2.67\end{array}$ & $\begin{array}{r}1.12 \\
2.77\end{array}$ \\
\hline Inrem_resid & $\begin{array}{r}-0.02 \\
-0.34\end{array}$ & $\begin{array}{r}-0.62 \\
-8.75\end{array}$ & $\begin{array}{r}-0.61 \\
-9.72\end{array}$ \\
\hline Inrem_pred & $\begin{array}{r}0.04 \\
1.04\end{array}$ & $\begin{array}{r}-0.35 \\
-5.56\end{array}$ & $\begin{array}{l}-0.59 \\
-10.85\end{array}$ \\
\hline In TFP & $\begin{array}{r}0.46 \\
8.52\end{array}$ & $\begin{array}{r}-0.19 \\
-2.26\end{array}$ & $\begin{array}{r}-0.21 \\
-2.92\end{array}$ \\
\hline $\mathrm{N}$ & 200 & 200 & 200 \\
\hline
\end{tabular}

Estimated across eight 1-digit industries (excluding government employment) Over 1980-2004, with a full set of industry and year fixed effects. Robust t-stats in parentheses. 
Figure 16

\section{Total employment}

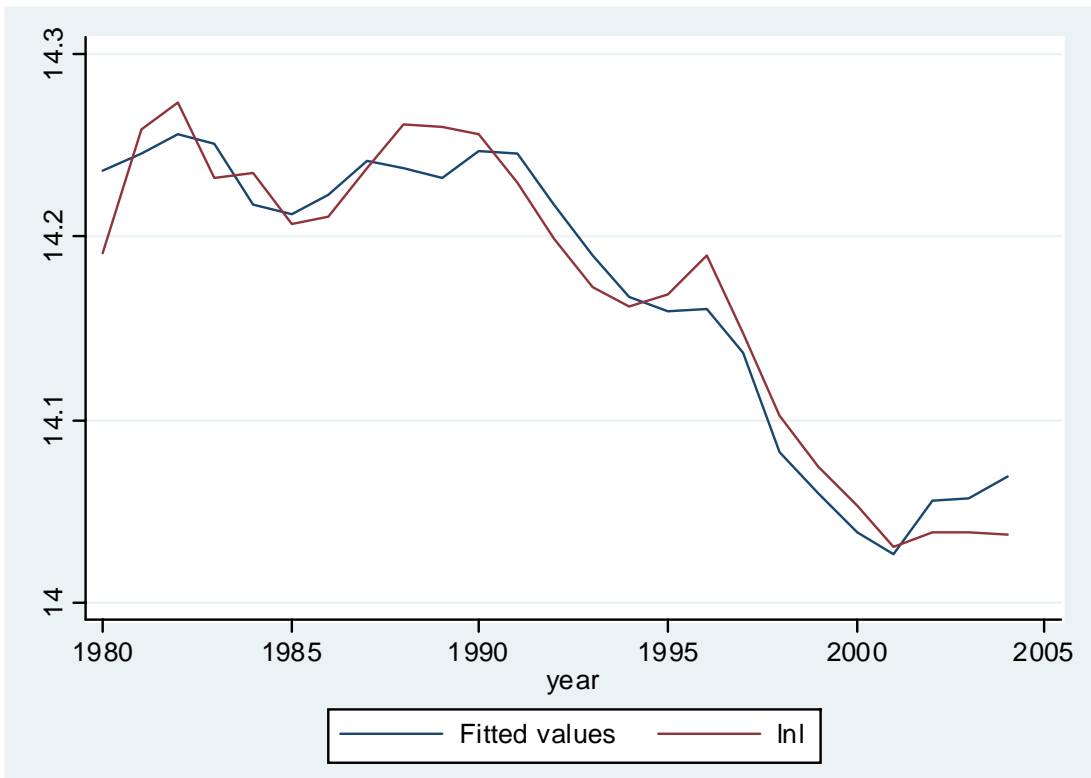

\section{Unskilled employment}

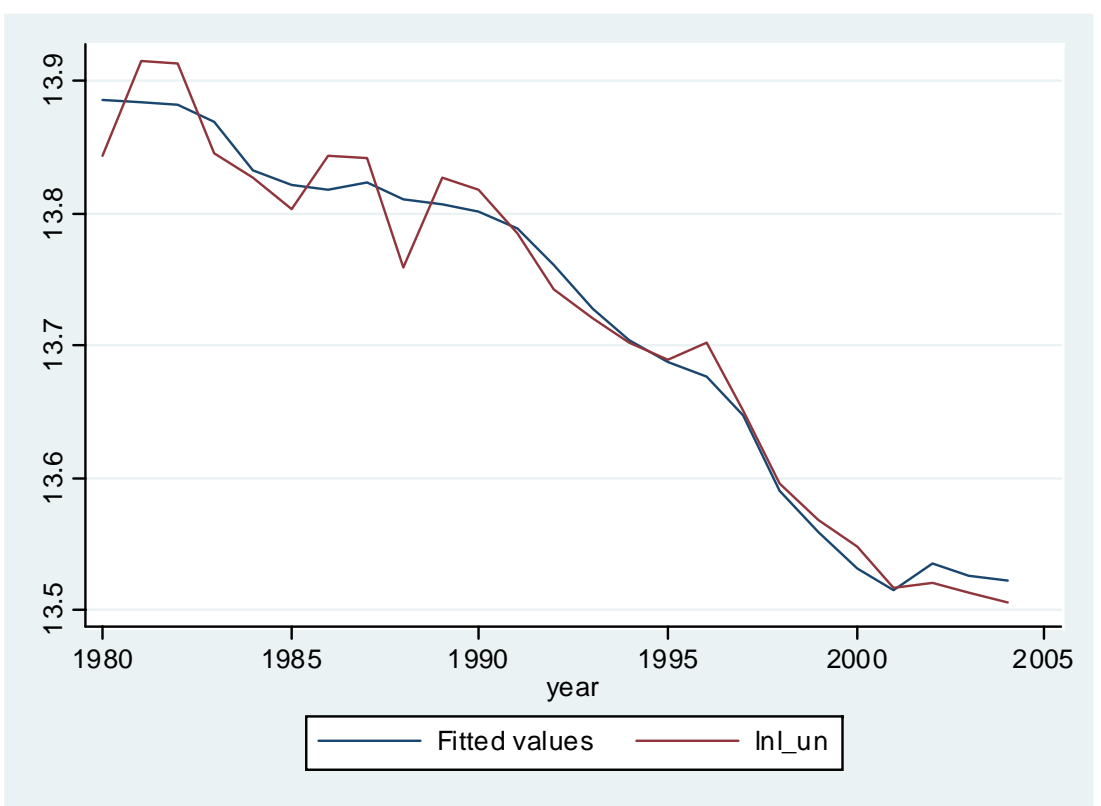

Explanatory variables used to generate the fitted values are: $\ln p \_$pgdp, lnrem_resid, lnrem_pred, lntfp. 
Table 6: Explaining the fall in manufacturing employment

Total employment (manufacturing)

\begin{tabular}{|c|c|c|c|c|c|c|}
\hline & $\ln I$ & Inp_pgdp & Inrem residual & $\begin{array}{l}\text { Due to: } \\
\text { Inrem_predicted }\end{array}$ & Intfp & total \\
\hline $1980-1990$ & 14.24 & 0.17 & 0.15 & 10.77 & 4.48 & \\
\hline 1994-2004 & 14.09 & 0.02 & -0.11 & 11.10 & 4.57 & \\
\hline log-points diff & -0.14 & -0.14 & -0.26 & 0.32 & 0.09 & \\
\hline coefficient & & 1.445 & -0.624 & -0.347 & -0.187 & \\
\hline contribution & & -0.21 & 0.16 & -0.11 & -0.02 & -0.17 \\
\hline (percent) & & $143.8 \%$ & $-113.0 \%$ & $78.2 \%$ & $11.2 \%$ & $120.2 \%$ \\
\hline
\end{tabular}


Figure 17

Profitability of manufacturing (SIC 3) relative to F.I.R.E. (SIC 8)

(measured by gross operating surplus per capital)

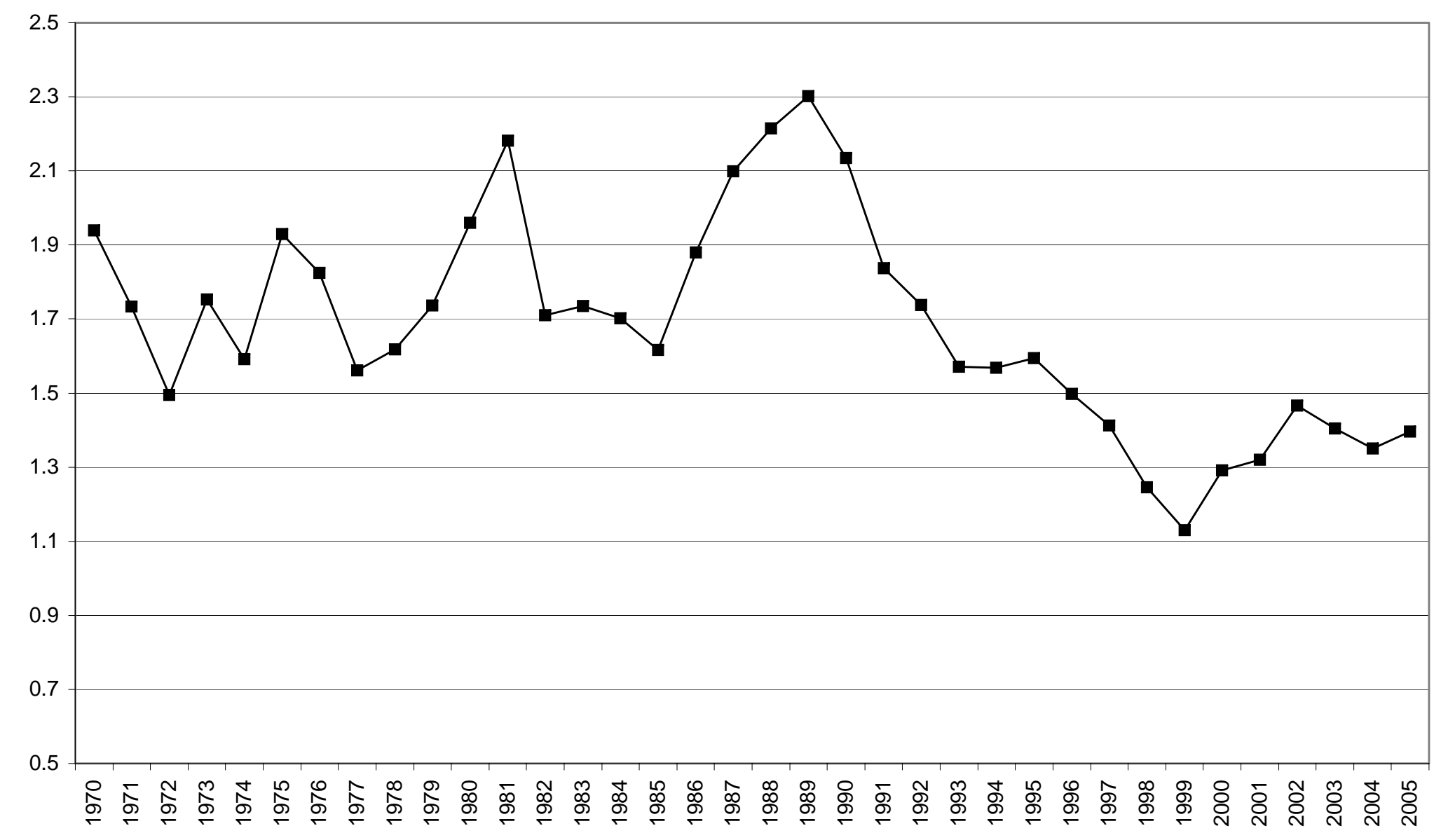


Table 7

Dependent variable: Inp_pgdp

\begin{tabular}{|c|c|c|c|c|}
\hline \multirow{3}{*}{$\begin{array}{l}\text { estimated coefficient } \\
\text { t-stat }\end{array}$} & \multirow{2}{*}{$\frac{\text { In TOT }}{0.09}$} & In RER & import & time \\
\hline & & -0.1 & -0.006 & -0.009 \\
\hline & 1.03 & -2.5 & -2.72 & -5.73 \\
\hline 0.92 & & & & \\
\hline 25 & & & & \\
\hline
\end{tabular}


Figure 18

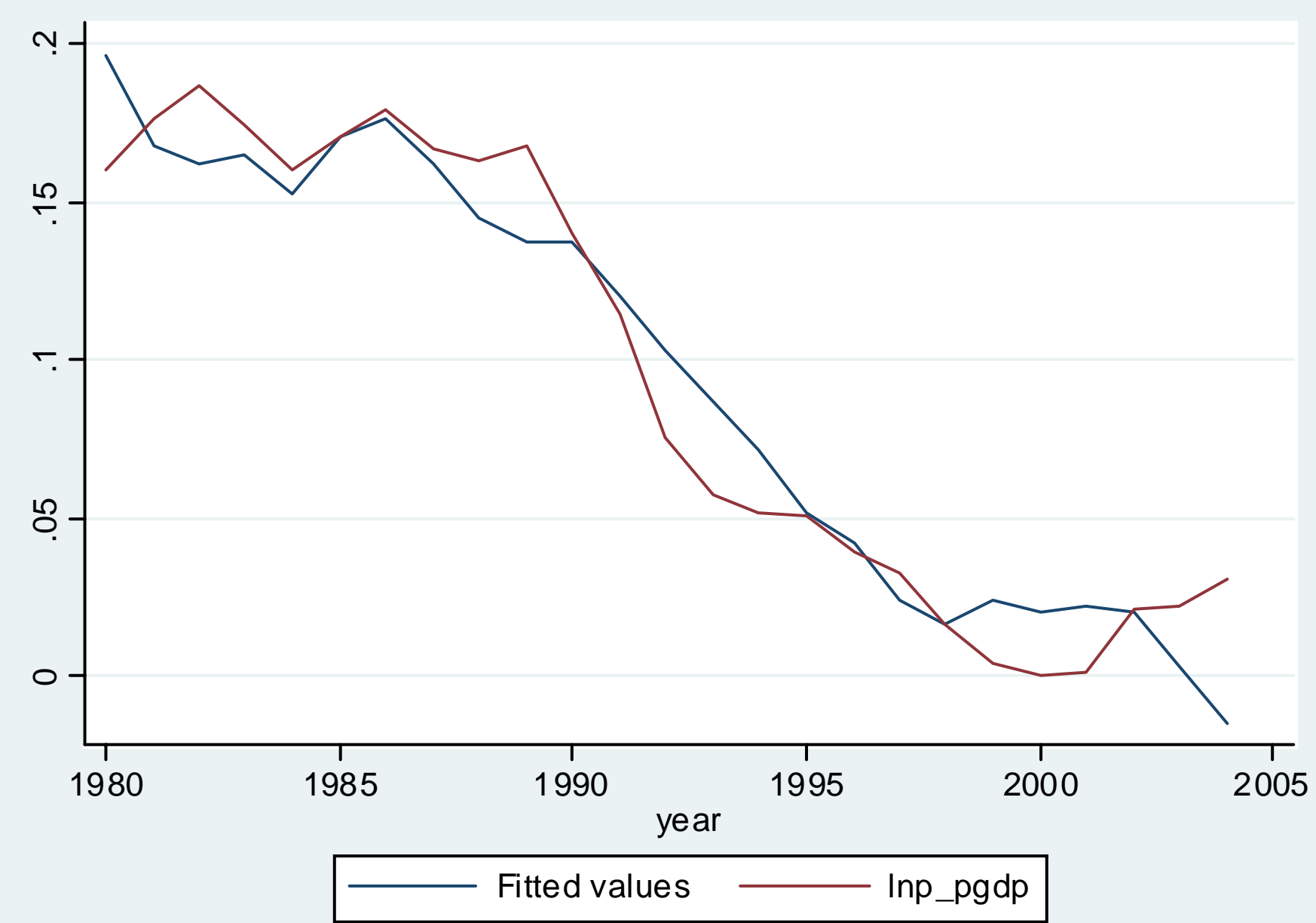


Table 8

Relative price of manufacturing

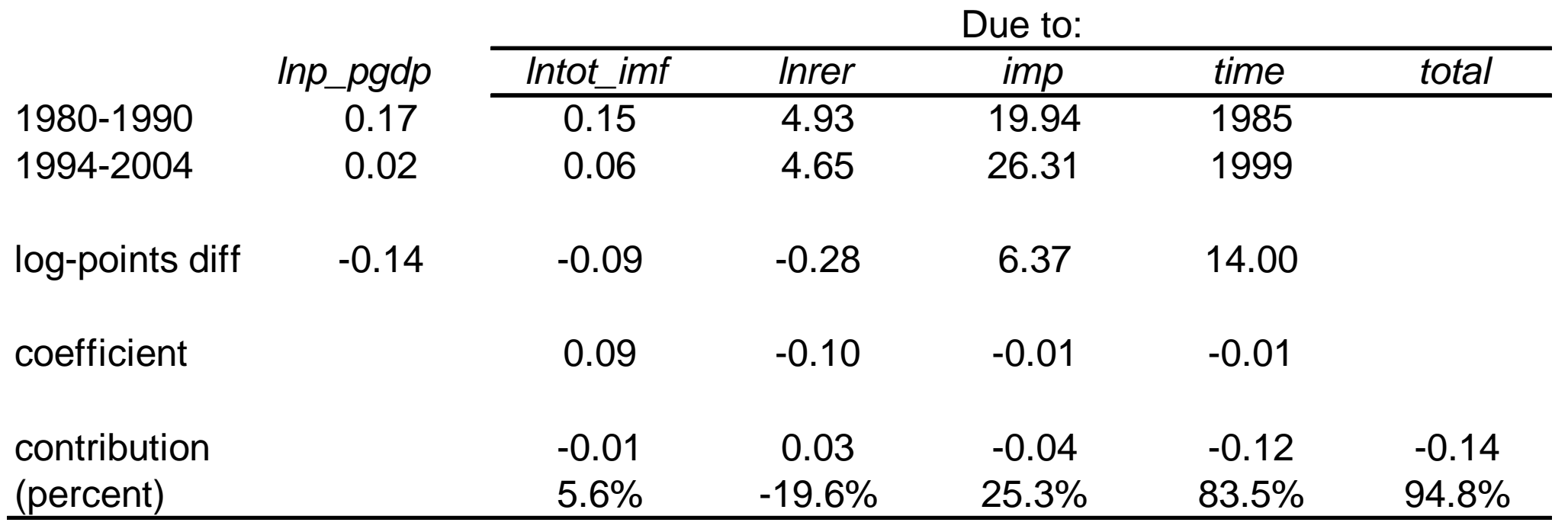


Table 9

Fixed effects regressions across manufacturing subsectors

dependent variable:

Inp_pgdp In employment

(1) (2)

\begin{tabular}{lcc} 
import penetration & -0.003 & -0.008 \\
& -4.18 & -5.58 \\
export ratio & 0.002 & 0.006 \\
& 2.80 & 4.73 \\
Inrem_resid & & -0.289 \\
& & -7.76 \\
Inrem_pred & & -0.663 \\
& & -5.11 \\
Intfp & & -0.001 \\
& & -0.03 \\
$N$ & 980 & 700 \\
\hline
\end{tabular}

Estimated with a full set of year and subsector dummies across 28 manufacturing subsectors

over the periods 1970-2004 (col. 1) and 1980-2004 (col. 2).

T-stats are shown under the coefficients. 